\title{
Türk Mimarisinin Günümüze Kadar Geldiği Yerleşim: Tarhala
}

\section{The Settlement on which Turkish Architecture has Survived until Today: Tarhala}

\author{
Ramazan Uykur $^{1}$ (D)
}

'Sorumlu yazar/Corresponding author: Ramazan Uykur (Doç. Dr.),

Manisa Celal Bayar Üniversitesi, Fen Edebiyat Fakültesi, Sanat Tarihi Bölümü, Manisa, Türkiye

E-posta: reuykur@gmail.com

ORCID: 0000-0001-5621-3687

Başvuru/Submitted: 13.01.2020

Revizyon Talebi/Revision Requested:

07.05.2020

Son Revizyon/Last Revision Received:

13.05.2020

Kabul/Accepted: 15.05 .2020

Online Yayın/Published Online: 30.06 .2020

Atıf/Citation: Uykur, Ramazan, "Türk

Mimarisinin Günümüze Kadar Geldiği Yerleşim: Tarhala". Sanat Tarihi Yıllığı - Journal of Art History 29 (2020), 247-278

https://doi.org/10.26650/sty.2020.011

\section{ÖZ}

Makalenin konusu Manisa İli'nin Soma ilçesine bağlı, günümüzdeki adı Darkale olan yerleşim yerindeki Türk dönemine ait yapıların tanıtılmasıdır. Tarhala, Antik dönemde ve Roma döneminde Pergamon'u doğudan gelecek tehlikelere karşı koruyan bir karakol niteliğindedir. Bizans ve Türk dönemlerinde aralıksız devam eden iskân günümüze kadar devam etmiştir. Tarhala isminin menşei konusunda farklı görüşler ileri sürülmüştür. Osmanlı arşiv kayıtlarında Tarhala olan yerleşim, Cumhuriyet dönemine Darkale ismini almıştır. Günümüzde Tarhala çok az sayıda hanenin yaşamaya devam ettiği, kaderine terk edilmiş bir yöredir. Köyde yaşamın terk edilmesiyle özellikle geleneksel konutlar büyük tahribata uğramıştır. Yerleşmede yaptığımız araştırmada Klasik Osmanlı döneminden kalma 1 metruk hamam, 19. yüzyıl Osmanlı döneminde yapılmış 2 cami, 14-15. yüzyıl özellikleri gösteren 1 çamaşırhane, 5 sağlam ve 2 metruk çeşme tespit edilmiştir. Anahtar kelimeler: Soma, Tarhala, Darkale, Osmanlı Mimarisi, Batı Anadolu

\section{ABSTRACT}

The subject of the article is the introduction of structures belonging to the Turkish Period in the settlement recently called Darkale, located in the Soma district of the Manisa province, together with its drawings and architectural features. During the Ancient and Roman periods, Tarhala used to serve as an outpost protecting Pergamon against the threats coming from the east. The constant habitation in the Byzantine and Turkish periods has continued until today. There have been many speculations about the the origin of the name Tarhala. In the Ottoman archives, the settlement is mentioned as Tarhala; and it took the name Darkale during the Republican Period. Today, Tarhala is an abandoned area on which a few householders continue to live. Due to such desolation, traditional houses have been extensively damaged. During the search we carried out in the settlement, we detected 1 abandoned bathhouse dating back to the Classical Ottoman Period, 2 mosques built in the 19th century, 1 laundry house bearing the characteristics of the 14th and 15th centuries, and 5 solid and 5 abandoned fountains.

Keywords: Soma, Tarhala, Darkale, Ottoman Architecture, Western Anatolia 


\section{Tarhala İsminin Menşei ve Yerleşimin Tarihçesi}

Tarhala, Ege Bölgesi’nde, Bakırçay havzası içinde yer alan, Manisa İli’nin Soma ilçesine bağlı, günümüzdeki adı Darkale olan yerleşim yeridir. ${ }^{1}$ Tarhala köyü vadi içerisinde eğimli bir yamaca yerleşerek, mimarinin doğa ve topoğrafya ile uyumlu biçimde bölgeye özgü bir yerleşme yapısı oluşturmuştur. ${ }^{2}$

Tarhala'nın Bergama Krallığı devrinde bir uç karakol görevi gördüğü ve M.Ö. 185 yılında kurulduğu ileri sürülmüştür. ${ }^{3}$ Antik dönemde Mysia bölgesinin sınırları içinde kalan yerleşim, Bergama Krallığı'nın önemli şehirlerinden olan Pergamon'un territoriumunda yer almıştır. ${ }^{4}$ Tarihi kaynaklar kuruluş yeri olarak Asartepe mevkiini göstermekte ve burada bir gözetleme kulesi, bir hamam ve Bağlararası çevresinde sayfiye evleri kalıntılarının varlığından söz etmektedir. ${ }^{5}$ M. Ermiş'in tespitlerine göre; Asar Tepe'de yan yana iki birimden oluşan gözetleme kulesi olabilecek bir tahkimat kalıntısı, Temenni Tepesi üzerinde de $70 \mathrm{~m}$. uzunluğunda bir savunma hattı bulunmaktadır. Bu savunma yapıları sayesinde yerleşmenin, Roma döneminde Pergamon'u doğudan gelecek tehlikelere karşı koruyan bir garnizon niteliğinde olduğu ifade edilmiştir. ${ }^{6}$

Tarhala adının ilk ne zaman kullanıldığına dair kesin bilgiler yoktur. Tarhala’nın kazılmış çukurlar, arklar, toprak tabyalar anlamına gelen "Tafrala" kelimesinden ${ }^{7}$ ve köy yakınlarındaki üç tepe Asartepe, Temenni ve Karşıyaka'ya atfen üç güzel anlamına gelen "Tiri kale” ile ilişkili olarak ortaya çıktığı ileri sürülmektedir. ${ }^{8}$ Osmanlı arşiv kayıtlarında Tarhala'nın değişik imlâlarla yazılması, yörenin adının zaman zaman Tırhala şeklinde yazılıp söylenmesine sebep olmuştur. ${ }^{9}$ Uzunçarşılı ise Saruhana tâbi şehirleri sayarken yerleşimin adını Tarhanya, Tarhanat ya da Meltemiye olarak farklı şekillerde anmaktadır. ${ }^{10}$

Ramsay, yerleşimin adının Geç Bizans döneminde Trakoula olduğunu, ismin daha sonra Trakhala olarak muhafaza edildiğini ve bu dönemde Soma'nın da Trakoula'ya bağlı bir yerleşim yeri olduğunu ifade etmiştir. ${ }^{11}$

1 Vehbi Günay, “XVI. Yüzyılda Tarhala Örneğinde Batı Anadolu'da İskân Değişimi”, Tarih İncelemeleri Dergisi, Cilt XXI, Say1 1, 2006, s. 108.

2 Figen Akpınar, "Bir Yerel Koruma Çabasının Öznesi Olarak Darkale Köyü”, Ege Mimarlık, Ocak 2016, s. 23.

3 İhsan Kutlusoy, Soma, Tan Matbaası, İstanbul 1971, s. 11; Günay, a.g.e., s. 110.

4 Ü. Melda Ermiş, "Darkale in The Byzantine Period: Settlement And Some Architectural Notes", Turkish Studies, Volume 11/1 Winter 2016, s. 61.

5 Gamze İlhan, Manisa Soma'da Bulunan Türk Devri Yapıları, Çanakkale Onsekiz Mart Üniversitesi, S. B. E., (Yayımlanmamış Yüksek Lisans Tezi), Çanakkale, 2019, s. 7.

6 Ermiş, a.g.e., s. 62-63.

7 Mine Tanaç Zeren, "Soma-Darkale Kültür Mirasının Korunması Ve Yerel Kalkınmanın Sağlanması İle İlgili Bilimsel Görüş (Rapor) Taslak”, Dokuz Eylül Üniversitesi Mimarlık Fakültesi Mimarlık Bölümü, Mart 2011, s. 1.

8 Avni Altıner, “Tarhala Obasını Tanıyalım”, Gediz, Cilt 1, Sayı 4, Manisa Halkevi Dergisi, 1937, s. 9; 14; Günay, a.g.e., s. 108.

9 Günay, a.g.e., s. 109.

10 İsmail Hakkı Uzunçarşı1ıoğlu, Kitabeler II, Devlet Matbaası, İstanbul, 1347/1929, s. 70-71.

11 W. M. Ramsay, The Historical Geography of Asia Minor, Volume IV, Royal Geographical Society, Supplementary Papers, London 1890, s. 127; Ayda Arel, "Soma Yakınlarında Eski Bir Dağ Yerleşmesi: Tırhala Köyü” IX. Araştırma Sonuçları Toplantısı, Çanakkale, 27-31 Mayıs 1991, A. Ü. Basımevi, Ankara 1992, s. 119; Günay, a.g.e., s. 110. 
Cumhuriyet dönemine 1968 yılında yerleşimin adı Türkçeleştirilerek Darkale ismini almıştır. ${ }^{12}$ Fakat Darkale adının köye verilmeden çok daha önce A. Altıner'in 1937 yılında yazdığı neşrinde geçiyor olması aslında ismin 1968'den önce biliniyor olduğunu göstermektedir. Altıner, bu hususta Salname-i Osmani'de köyün adının Darkale şeklinde geçtiğini ve bunun Selçuklular tarafından verildiğini belirtmiştir. ${ }^{13}$

Tarhala'nın Türklerin eline geçişi ise köydeki rivayetlere göre Horasan'dan gelen Kaleli Hoca, İsa Bey ve Gündüz Bey gibi beylerle gerçekleşmiştir. Altıner, söz ettiği yılda hâlâ köy mezarlığında; Gündüzler Sülalesi, Kaleli Oğulları ve İsabey Oğulları gibi birkaç yüzyıllık mezar taşlarının bulunduğunu ve köyde yaşayanlar arasında bu lâkapları taşıyan ailelerin varlığından söz etmiştir. ${ }^{14}$

Manisa 1313 tarihinde Saruhan Bey tarafından Bizanslılar'dan alınarak yönetimin merkezi yapılmıştır. ${ }^{15}$ Manisa'da anlatılan rivayete göre Saruhan Bey Bizanslılar ile savaş öncesinde, askerlerini çok göstermek için gece keçilerin boynuzlarına mum yakarak Spil Dağı'na ve ovaya bunları salıvermiş. Böylece büyük bir ordunun geldiğini sanan Bizanslılar korkarak mağlup olmuş ve Manisa kalesi Türklerin eline geçmiştir. ${ }^{16}$

Tarhala'nın ele geçirilmesinde de aynı taktiğin kullanıldığı ve Horasan'dan gelen Türkmen aşiretlerin burayı ele geçirdiği rivayet edilmektedir. Bu itibarla Uluçay ve Gökçen, kuzeye yerleşen Türklerin Manisa'dan önce Tarhala'yı yönetimin ilk merkezi yaptıklarına ihtimal vermektedir. ${ }^{17}$

Osmanlı dönemi idari teşkilatlanmasında Hudâvendigâr Sancağı'nın 1487 yılına ait Tahrir Defterleri'nde otuz iki idari biriminden biri ve 1520-1530 arasındaki tahrirlerin sonuçlarını yansıtan Anadolu Vilayeti İcmâl Defterine göre sancakta kaza statüsü içinde gösterilen yirmi beş birimden biri Tarhala kâzası olduğu kayıt edilmiştir. ${ }^{18} 16$. yüzyılda da Hüdavendigâr livâsı içinde yer alan kâza merkezlerinden biri olan Tarhala'nın 2 mahalle, 59 köy, 24 mezra, 9 çiftlik, 4 cemaati ve 223.311 akçe geliri bulunmaktadır. ${ }^{19}$ Tarhala kâzasının 16. yüzyıl sonu ve 17. yüzyıl başlarında geçirdiği değişim V. Günay’ın yayınladığı Manisa Şeriyye Sicilleri, 1603-04 yılı defterinde "Tarhala kâzasına tâbi nefs-i Soma" kaydı mevcutken, 1607-08 tarihli defterde "Kâza-i Soma" ibaresine dönüştüğü görülmektedir. ${ }^{20}$

İ. Gökçen'in verdiği bir malumatta, III. Murat'ın şehzade iken Manisa' da yaptırdığg 1 Muradiye Cami’nin vakıf ve kaynakları arasında, Tarhala kâzasında bir tahinhanenin vakfedildiğini gösteren belge bulunmaktadır. ${ }^{21}$

12 Günay, a.g.e., s. 108; Arel, a.g.e., s. 119.

13 Altıner, a.g.e., s. 9.

14 Altıner, a.g.e., s. 9; Günay, a.g.e., s. 110; Kutlusoy, a.g.e., s. 153.

15 İsmail Hakkı Uzunçarşılıŏglu, Kitabeler II, Devlet Matbaası, İstanbul, 1347/1929, s. 59.

16 Çă̆atay Uluçay ve İbrahim Gökçen, Manisa Tarihi, Resimli Ay Matbaası, İstanbul, 1939, s. 22-23.

17 Uluçay ve Gökçen, a.g.e., s. 22-23.

18 Feridun Emecen, "Hudâvendigâr", DİA, Cilt 18, 1998, s. 285, 286.

19 Günay, a.g.e., s. 111, 112. Ayrıca İ. Gökçen' in yayınladığı, 16. ve 17. yüzyıllarda Manisa dolaylarındaki Yörük ve Türkmenlere dair vesikalar arasında Tarhala'nın bir kâza olduğu ve yörede Hamitlü cemaatinin varlığını görmekteyiz. Bk. İbrahim Gökçen, Saruhan'da Yörük ve Türkmenler, Marifet Basımevi, İstanbul, 1946, s. 28-29.

20 Günay, a.g.e., s. 116.

21 İbrahim Gökçen, Manisa Tarihinde Vakıflar ve Hayırlar I, Marifet Basımevi, İstanbul, 1946, s. 221. 
Yerleşim, 1865 yılından sonra kâza merkezi olma özelliğini yitirerek köy konumuna gerilemiştir. Bu dönemde Tarhala kâzası, Soma ve Kırkağaç ilçeleri ile bu ilçelere bağlı belde ve köy yerleşimlerini de içerisine alan geniş bir coğrafi bölgeyi kapsamaktadır. ${ }^{22}$

Cumhuriyet döneminde, Tarhala köyü ticaretle uğraşan ve bu ticari faaliyetleri üzüm ve kiraz bayramları gibi şenliklere dönüştürerek bunları İzmir gibi civardan katılımlarla birlikte kutlayan tüccarlardan oluşan bir yöredir. ${ }^{23}$

\section{TARHALA'DA TÜRK MIMMARİSI}

\section{Hamam}

Tarhala Köyü girişinden, Kırkoluk Meydanı’na doğru çıkarken yolun solunda, dere kenarında hamam yer almaktadır. Kitabesi bulunmadığı için yapım tarihi hakkında kesin bir şey söylemek zordur. Yapı, Kültür Bakanlığg Gayrimenkul Eski Eserler ve Anıtlar Yüksek Kurulu Başkanlığı'nın 8.7.1977 tarih ve A.633 sayılı kararıyla eski eser olarak tescillenmiştir. ${ }^{24}$

\section{Yapının Tarihi}

Eserin tarihlendirmesi hakkında M. Çerkez, yapıyı plan, malzeme ve mimari özelliklerine bakarak Klasik Osmanlı dönemine tarihlendirmiştir. ${ }^{25}$ V. Günay’ın yayınladığı, 16. yüzyılın ilk yarısına ait tahrir defterlerinde yapı kayıtlıdır. Burada Tarhala Kâzası'nda imâr faaliyetleri arasında hamamın gelirlerinin buraya tâbi Soma Mahallesi’ndeki Orhan Bey Mescit ve Muallimhânesine vakıf olarak bırakıldığı kaydı bulunmaktadır. ${ }^{26} \mathrm{Bu}$ kayda göre 16. yüzyılın ilk yarısında hamamın var olduğunu, dolayısıyla bu tarihten daha önce yapılmış olduğunu anlıyoruz. Bu bilgiler ışı̆̆ında yapının 16. yüzyıl başlarında inşâ edilmiş Klasik Osmanlı dönemi hamamı olduğunu söyleyebiliriz.

\section{Yapının Mimari Analizi}

Kesme taş, kaba yonu taş ve tuğla malzemeden inşâ edilen yapı bugün metruk haldedir. Kalıntılardan yapının doğ-batı yönünde konumlandığı ve üç kubbeden meydana gelmiş bir plan şemasına sahip olduğu anlaşılmaktadır. Kubbelerden biri tamamen çökmüş ve kalıntısı hâlâ çöktüğü yerdedir. Diğer iki kubbe sağlamdır. Çeşitli sebeplere dayalı olarak tahribat çok fazla olduğu için bu haliyle hamamın planını anlayabilmek mümkün değildir. Alanda yapılacak ayrıntılı temizlik çalışmaları, çevresini saran ve yapıyı tahrip eden ağaçların kesilmesi ve kurtarma kazılarından sonra yapının planını anlamak ancak mümkün olacaktır (F1-F3).

22 Gülşah Uçarkuş, Manisa Soma Darkale Mahallesi Geleneksel Konutları, Trakya Üniversitesi S. B. E. Sanat Tarihi A. D. (Yayımlanmamış Yüksek Lisans Tezi), Edirne 2019, s. 7.

23 Avni Altıner, "Soma Tarhala Köyünde Kiraz Bayramı”, Gediz, Cilt 4, Sayı 38, Manisa Halkevi Dergisi, 1940 , S. 13.

24 Bk. İzmir II Numaralı Kültür Varlıklarını Koruma Bölge Kurulu Arşivi.

25 Murat Çerkez, "Soma İlçesi”, Türk Kültür Varlıkları Envanteri 45, Manisa İlçeleri, Ed. Hakkı Acun, TTK Yayınları, Ankara, 2013, s. 455.

26 Günay, a.g.e., s. 114. 
Ayakta kalabilmiş mekânların değerlendirmesinin ise şöyle olabileceği kanaatindeyiz: Doğuda dikdörtgen bir kapıdan kare bir bölüme girilmektedir. Mekândaki kalıntılar bu bölümün hamamın soyunmalık kısmı olduğunu düşündürmektedir. Bu mekânın üzeri kubbeyle örtülüdür ve kubbeye geçiş elemanı olarak tromp kullanılmıştır. Buradan sivri kemerli bir kapıyla kareye yakın, kubbeli başka bir mekâna geçilmektedir. Bu mekân muhtemelen 1lıklık olmalıdır. ${ }^{27}$ (F1-F2) Buradan da yine kare planlı ve kubbeyle örtülü başka bir mekâna girilir. Kubbenin içinden buranın sıcaklık bölümü olduğu anlaşılır (F3). Bunun dışında hamamın diğer mekân ve mimari elamanlarının yerlerini ve özelliklerini tespit edebilme imkânı yoktur.

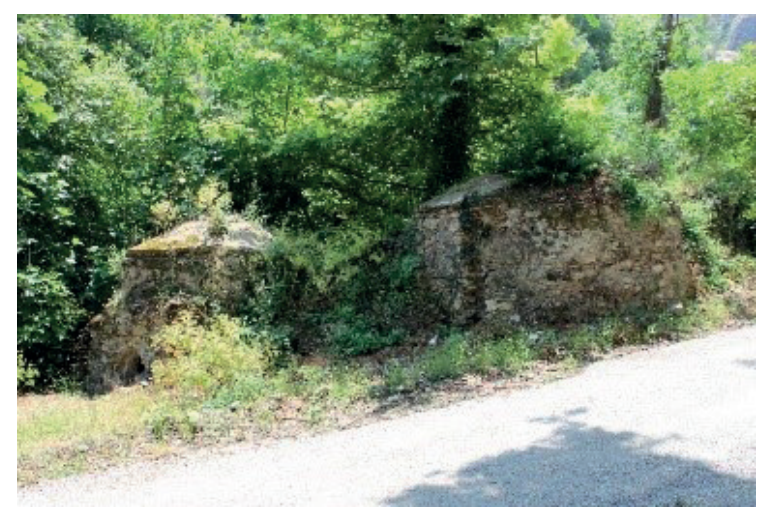

F. 1: Hamam, doğudan genel görünüş (2019)

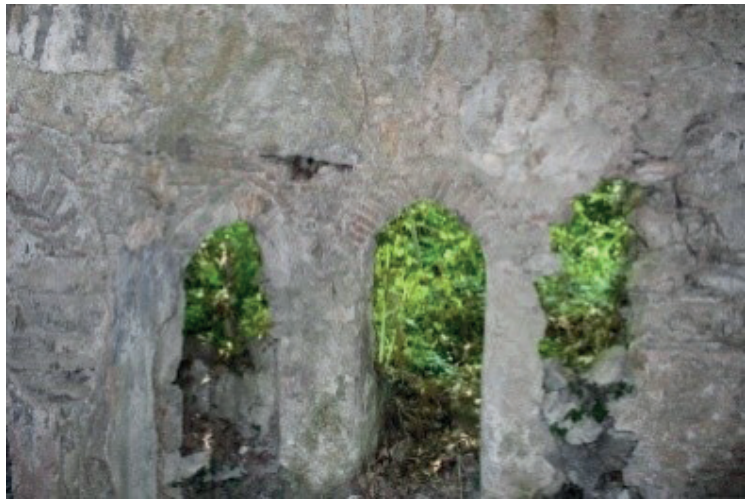

F. 2: Hamamın içinin günümüzdeki durumu (2019)

27 Çerkez, a.g.e., s. 457. 

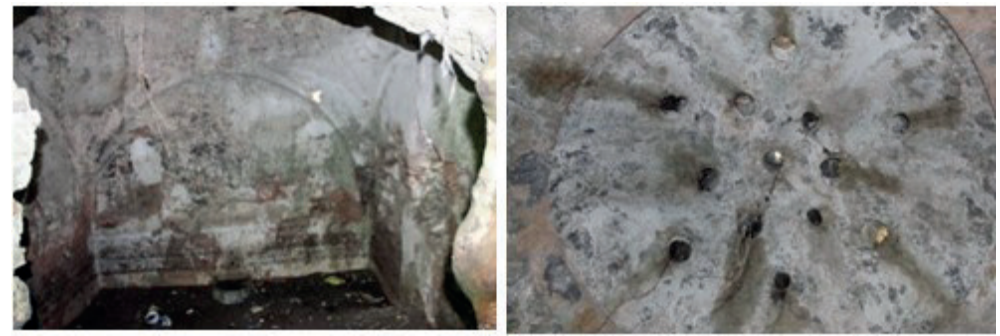

F.3: Hamamın sıcaklık bölümü ve sıcaklık bölümünün kubbesi (2019)

\section{Kırkoluk Cami}

Tarhala Köy meydanında köy yolunun sağında, dereyi örten sivri tonozlu geçidin üzerinde yer almaktadır. Yapı, Kültür Bakanlığı Gayrimenkul Eski Eserler ve Anıtlar Yüksek Kurulu Başkanlığı'’nın 8.7.1977 tarih ve A.633 sayılı kararıyla eski eser olarak tescillenmiştir²8 (F4-F11).

\section{Yapının Tarihi}

Yapıda, banisini ve inşâ tarihini açıkça belirten bir kitabe bulunmamakla birlikte ikisi son cemaat mahallinde harime giriş kapısının iki yanında, diğeri de kadınlar mahfilinin kuzey duvarında olmak üzere üç adet tarih yazılıdır. Bunlar yakın zamanda maalesef, Arapça harf ve rakamları bilmeyen Varol isimli usta tarafından özgün yazıların üzerinden yağlı boyayla boyanmak suretiyle tahrip edilmiştir (F14). Aynı durum caminin bütün kalemişi süslemelerinde de görülmektedir.

Yapının son cemaat mahallinin batı bölümünde harime giriş kapısının sağında "sene İkinci 1264 (1847-1848)" (F15-F16), son cemaat mahallinin doğu bölümünde, kapının solunda "sene İkinci 1321 (1903-1904)"29 (F12-F13) ve kadınlar mahfilinin kuzey duvarında da bozuk bir hatla "sene İkinci 1264 (1847-1848)" yazmaktadır (F18). Son cemaat mahallindeki tarihlerin caminin onarım tarihleri olduğu öne sürülmüştür. ${ }^{30}$ Fakat caminin Barok karakterli süslemeleri ile son cemaat mahallinin batı bölümündeki 1264 (1847-1848) yılı örtüşmektedir. Dolayıyla bu tarih, caminin inşâ tarihi olma ihtimalini güçlendirmektedir.

\section{Yapının Mimari Özellikleri}

Cami, dereyi örten, sivri tonozlu geçidin üzerinde, kısmen fevkâni, olacak şekilde kaba yonu taşla yığma olarak inşâ edilmiştir. ${ }^{31}$ Doğu-batı yönünde dikdörtgen bir harim; harimi doğu, batı ve kuzeyden U şeklinde çevreleyen kadınlar mahfili ve harimin kuzeyindeki son cemaat

28 Bk. İzmir II Numaralı Kültür Varlıklarını Koruma Bölge Kurulu Arşivi.

29 Yazıda özgün tarihin üzerinden boyama yapılırken ortadaki rakamın karakteri bozularak "F" harfi şeklinde yazılmıştır. Bu yüzden tarihin ikinci rakamı tarafımdan okunamamış ve M. Çerkez'in okuduğu 1321 tarihi esas alınmıştır. Bk. Çerkez, a.g.e., s. 438.

30 Çerkez, a.g.e., s. 438.

31 Zeren, a.g.e., s. 7. 
mahallinden meydana gelen yapı ahşap tavanlı ve kırma çatılıdır. Alt katın güney bölümünde, doğuya yani köyün meydanına açılan iki yuvarlak kemerli mekân bulunmaktadır. Bu mekânlar günümüzde taşla örülerek sağır hale getirilmiştir. Açık kemerli mekânların, döneminde dükkân olduğu ifade edilmektedir ${ }^{32}$ (F4-F7). Kuzey bölümü ise ortası havuzlu, dinlenmeye uygun, sosyal bir alan olarak tasarlanmıştır. Yapının batı, güney ve doğu duvarında zeminden yaklaşık $50 \mathrm{~cm}$. yüksekte mermer ayna taşları olan abdest muslukları sıralanmıştır (F22).

Yapının son cemaat mahalline kuzeybatı köşesindeki beton merdivenle çıkılabildiği gibi batı yönünden gelen patika bir yolla da ulaşılabilmektedir. Son cemaat mahalli doğu-batı yönünde dikdörtgen planlı ve ahşap tavanla örtülüdür. Son cemaat mahallinin doğusu dört yuvarlak kemerle kuzeye, iki yuvarlak kemerle de doğuya açılmaktadır. Kemerler ahşap sütunlarla taşınmakta, yüzeyleri bağdadi sıvayla kapatılmış, kemer araları ve kemer içleri ise bezemelidir (F11). Güney duvarında içi bezemeli yuvarlak nişli bir mihrap, mihrabın iki yanında alt ve üst sırada iki dikdörtgen pencere bulunmaktadır (F6, F12).

Son cemaat mahallinin batısı arazi şartlarından dolayı kapalı mekân şeklinde tasarlanmıştır. Buranın güney duvarında iki sıra pencere, kuzey doğusunda kadınlar mahfiline çıkış merdiveni yer almıştır (F15, F17).

Eserin doğu cephesi alt ve üst sırada, üçer dikdörtgen pencerelidir (F6, F8). Güney cephe üst sırada dört, alt sırada iki pencere düzenine sahiptir (F7, F9). Batı cephe sağır olarak yapılmışken, sonradan açılmış ve tekrar kapatılmış bir pencere izi görülmektedir (F7, F10).

Harim doğu-batı yönünde dikdörtgen planlıdır. Güney duvarının kapı aksında yuvarlak nişli bir mihrap bulunmaktadır. Mihrap nişi kalın bezemeli bir şeritle çevrelenmiştir (F19, F21).

Kadınlar mahfili ise harimi doğu, batı ve kuzeyden U şeklinde çevrelemiş ve ahşap sütunların taşıdığı, basık kemer sırası üzerinde inşâ edilmiştir (F20).

Mihrabın batısında özgün olamayan minber, harimin kuzeydoğusunda ise özgün vaaz kürsüsü bulunmaktadır. Son cemaat mahalli ve harim ahşap tavan örtülüdür.

\section{Süsleme}

Caminin Geç Osmanlı Döneminde yapılmış Barok karakterli özgün süslemelerinin tamamı aynı usta tarafından yağlı boyayla üzerlerinden geçilerek boyanmıştır.

Son cemaat mahallinin doğusunda kemer aralarında sarmaşıklar, kemer içlerinde iri akantus yapraklar; güney duvarında perde motifli mihrap nişinin içinde perdeden zincirle sarkıtılmış çiçekli vazo, vazonun iki yanında şamdan çizilmiştir. Mihrap kavsarasının üzerinde boğumlu perde motifi içinde sülüs hatla "Muhammed" yazılmıştır. Pencerelerin kenarları, büyük madalyonlar içinde çiçekler ve madalyonların çevresini sarmış iri akantus yapraklarıyla süslenmiştir (F12).

Son cemaat mahallinin batı bölümü, güney duvarda kalem işi perde motifleriyle bezenmiş mihrap görülmektedir. Mihrabın iç süslemesi kemerli bir çerçeveden sarkan kandil ve kandilin iki

32 Arel, a.g.e., s. 121. 
yanında duran şamdan motiflidir. Mihrap üzerinde dikdörtgen şerit içinde boğumlu perede motifi ve ortasında madalyon içinde sülüs hatla “Allah” yazmaktadır. Duvar yüzeyi ve pencere kenar süslemeleri, iri madalyonların çevresini sarmış üzümlü asma dalları ve sarmaşık çiçeklerden meydana gelmiştir (F15).

Son cemaat mahallinin batı duvarında yüksek bir ustalık gösteren Barok karakterli süslemeyle karşılaşılır. Yatay olarak uzanmış iki uzun çubuktan sarkan ve adeta rüzgârda uçuşuyor etkisi verilmiş perde motifleri ve çubukların birleşme noktasından sarkan Mühr-ü Süleyman içinde hattı bozulmuş yazıt yer almaktadır (F17).

Harimde bütün duvar yüzeyleri Barok üslupta süsleme özellikleri gösteren bitkisel bezemelerle doldurulmuştur. Harimin duvarlarında Hz. Muhammed ve dört halifenin isimlerinin bulunduğu sülüs hatlı yazılara yer verilmiştir. Boyama işini yapan ustanın bazı yazıların karakterlerini bozduğu görülmektedir. Mihrap duvarında ise süsleme daha da çeşitlendirilmiştir. Özellikle mihrabın nişi ve çevresi kullanım eşyalarından oluşan süslemelerle vurgulanmıştır. Mihrap nişi uzun şeritlerle üç dikdörtgen bölüme ayrılmış, her bölümün üzerinde üstten perdelerin sarktığı bir süsleme ayrıntısı işlenmiştir. Nişin orta bölümünde bir iple sarkıtılmış içinde üç adet mum yanan kandil, iki yanda ise yine üç adet mum yanan şamdan motifleri yer almıştır. Bütün bu tasarım bir bulut kümesinin içinde çizilerek adeta gökyüzüyle ilişkilendirilmiştir. Mihrap nişinin sağında ve solunda ayaklı şamdanlar ve servi ağaçları resmedilmiştir. Ayrıca mihrap kavsara köşeliklerinin ortasında müsennâ hatla "Muhammed" ve üzerindeki dikdörtgen çerçevede Al-i İmran Suresinin 37. Ayeti içinde mihrap geçen bölümü yazılmıştır (F21).

Yapının içinde kalem işlerinde gördüğümüz süslemelerin benzerleri, dışarda abdest musluklarının ayna taşlarında karşımıza çıkar. Abdest musluklarının ayna taşlarında Bizans dönemi devşirme taşlar kullanıldığ $1^{33}$ gibi, Geç Osmanlı dönemi üslubunda taşa kazınmış madalyonlar çevresinde akantus yaprakları, vazodan çıkmış çiçekler ve cami tasvirleri dikkat çekmektedir (F22-F23).

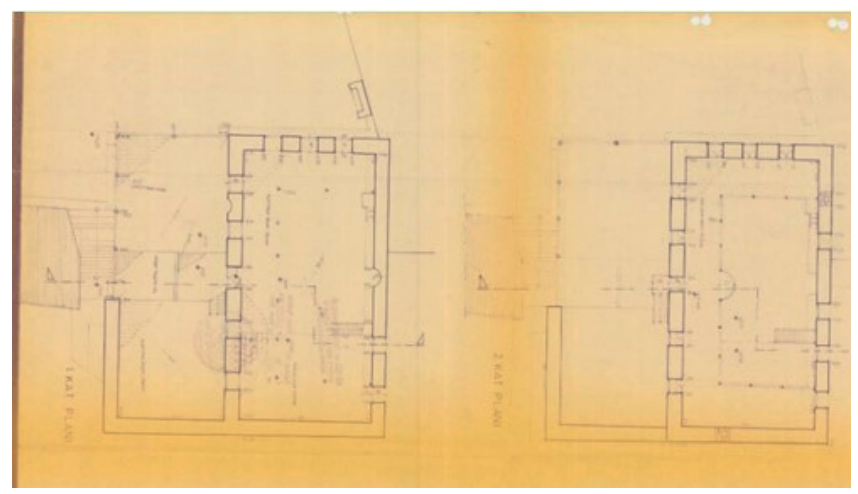

F. 4 - F. 5: Kurkoluk Cami, solda alt kat rölövesi, sağda üst kat rölövesi (Çizen Mimar Hasan Yavuz, 19.9.1985, İzmir II Numaralı Kültür Varlıklarını Koruma Bölge Kurulu Arşivi.)

33 Ermiş, a.g.e., s. 63, 67. 


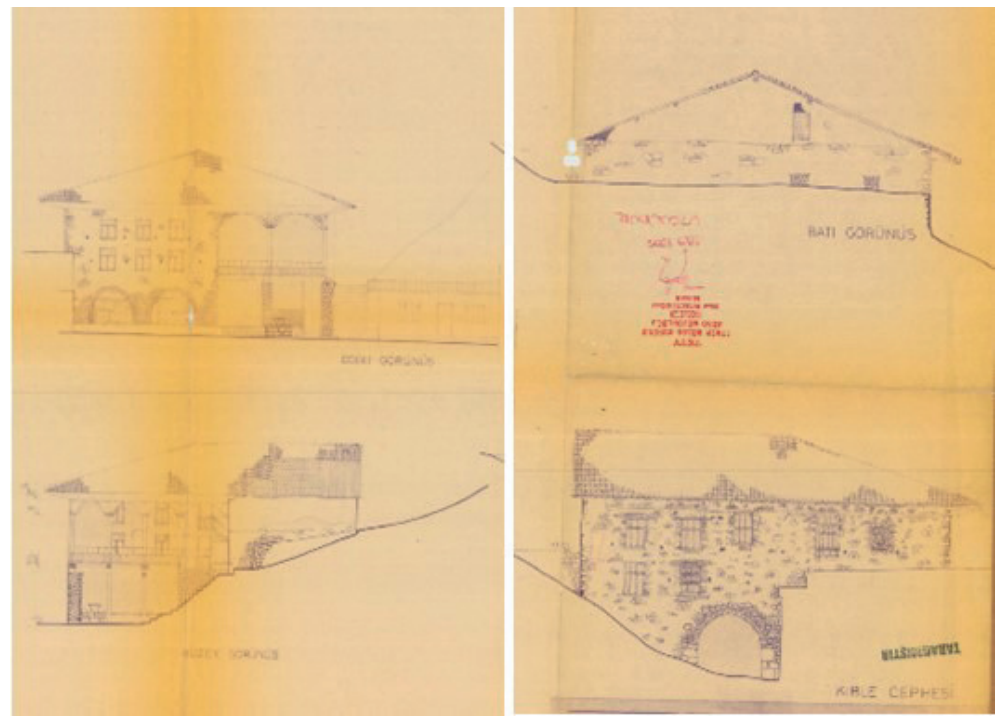

F. 6 - F. 7: Kırkoluk Cami cephe rölöveleri (Çizen Mimar Hasan Yavuz, 19.9.1985, İzmir II Numaralı Kültür Varlıklarını Koruma Bölge Kurulu Arşivi.)

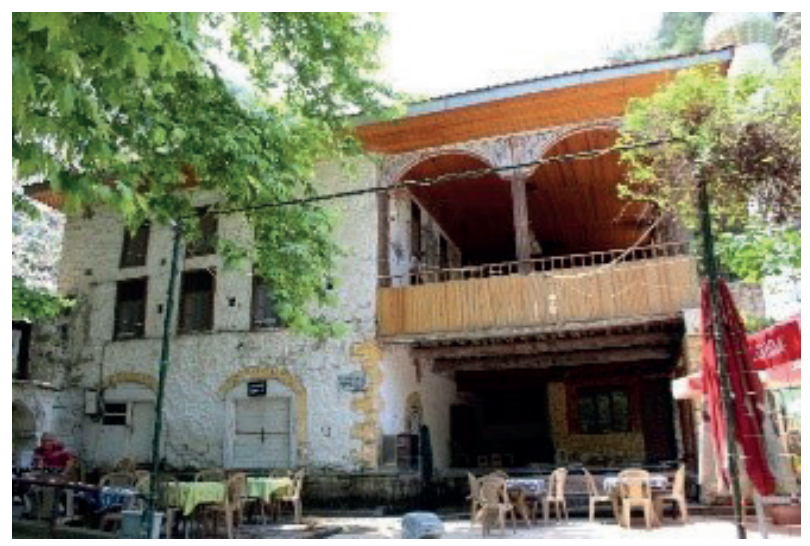

F. 8: Kırkoluk Cami, doğu cephesine bakış 


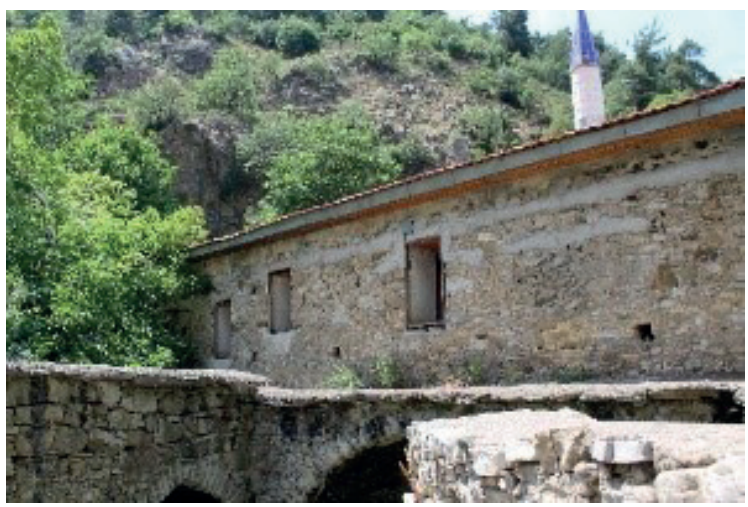

F. 9: Kırkoluk Cami, güney cephesine bakış

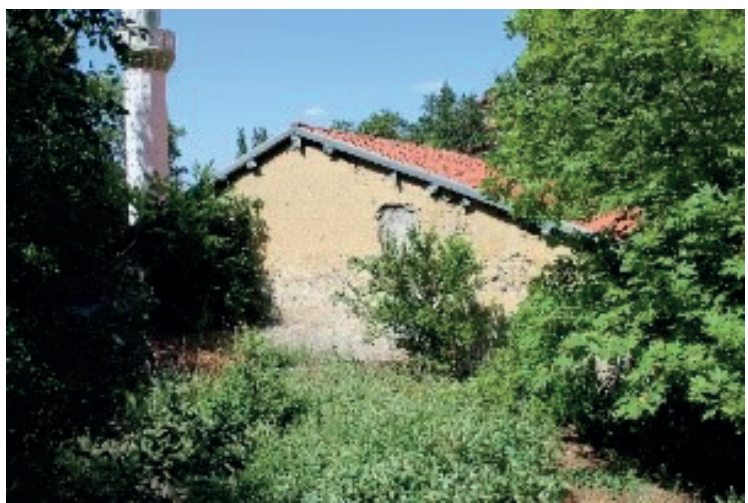

F. 10: Kırkoluk Cami, batı cepheye bakış

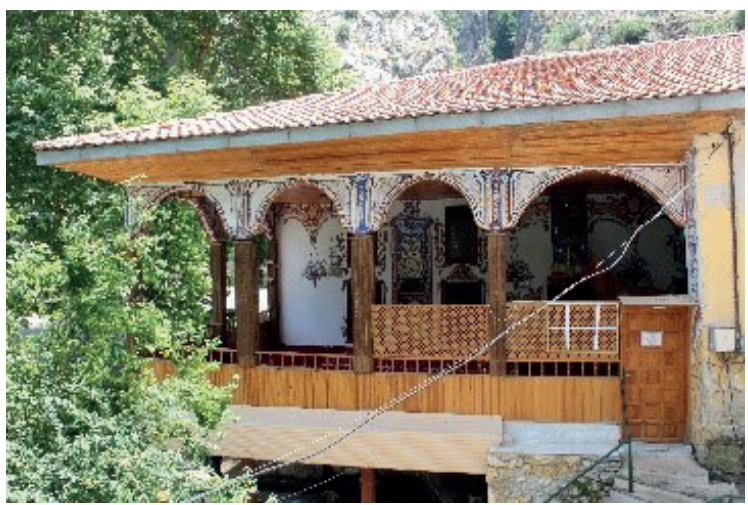

F. 11: Kırkoluk Cami, kuzey cepheye bakış 


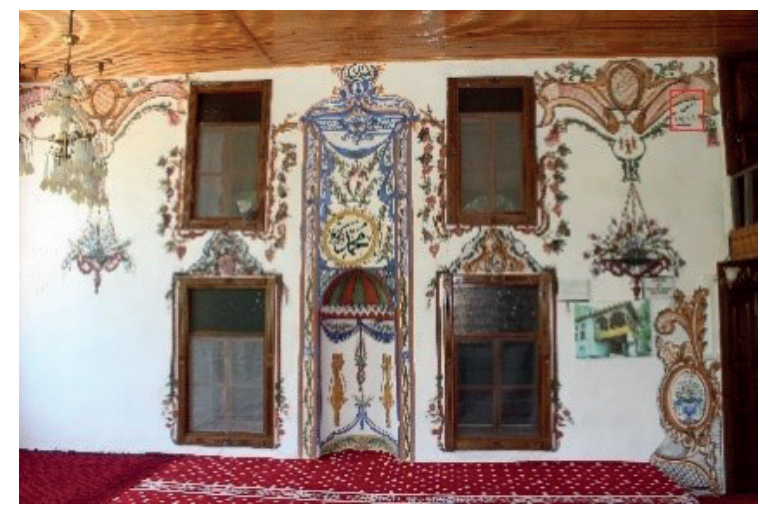

F. 12: Kırkoluk Cami, son cemaat mahalli doğu bölümü güney duvarı

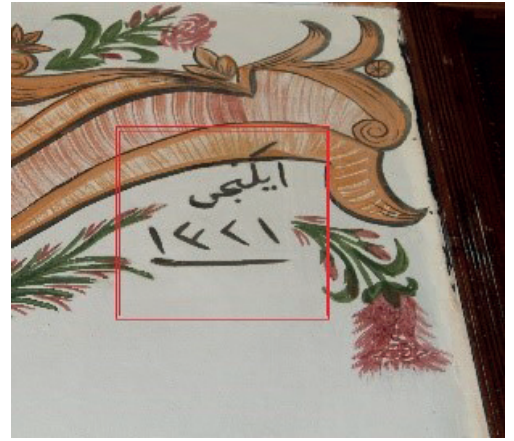

F. 13: Kırkoluk Cami, doğu bölümü tarih yazısının ayrıntısı

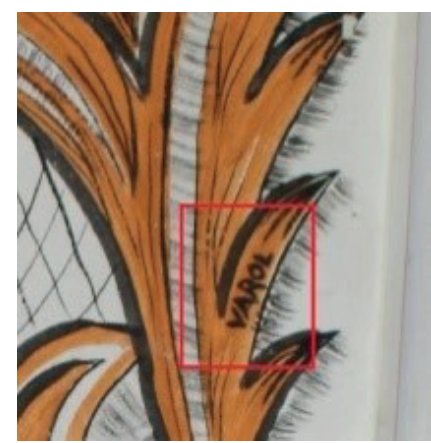

F. 14: Kırkoluk Cami, doğu bölümü boya ustasının adını yazdığ imzası

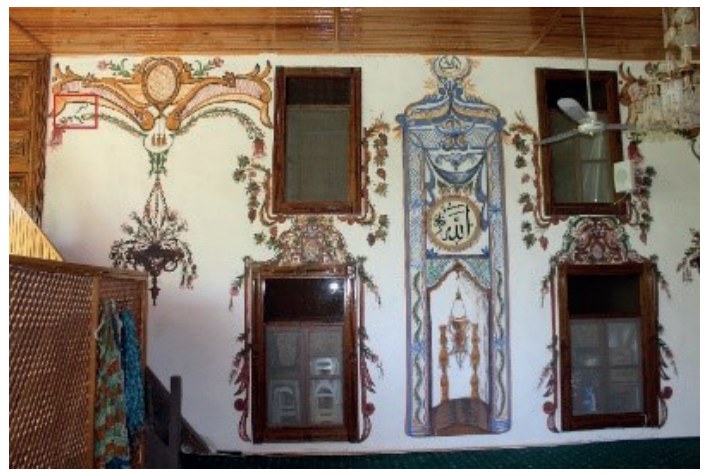

F. 15: Kırkoluk Cami, son cemaat mahalli batı bölümü güney duvarı 


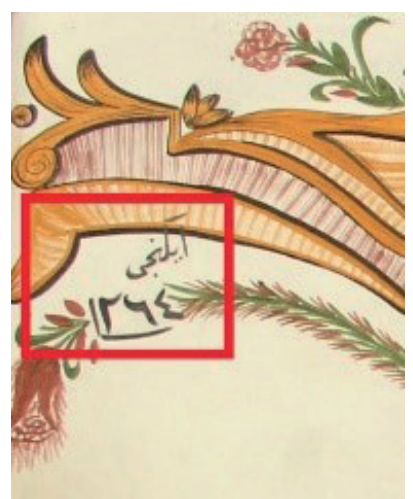

F. 16: Kirkoluk Cami, batı bölümünde tarih yazısının ayrintısı

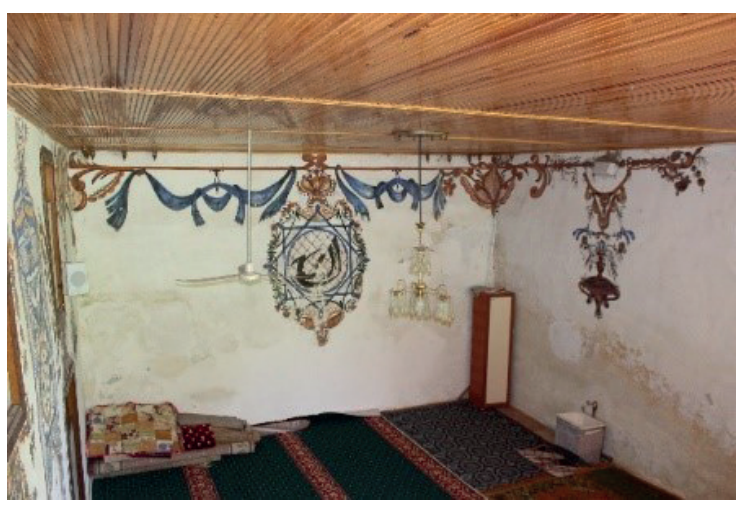

F. 17: Kırkoluk Cami, son cemaat mahalli batı duvarına bakış

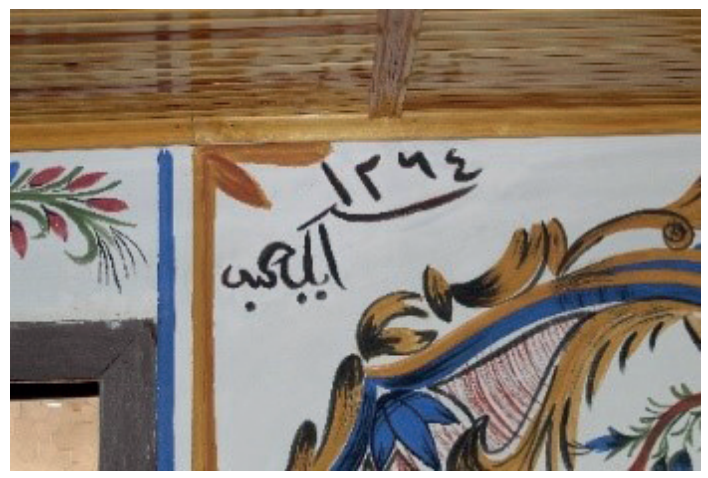

F. 18: Kırkoluk Cami, kadınlar mahfilinde yer alan tarih yazısı

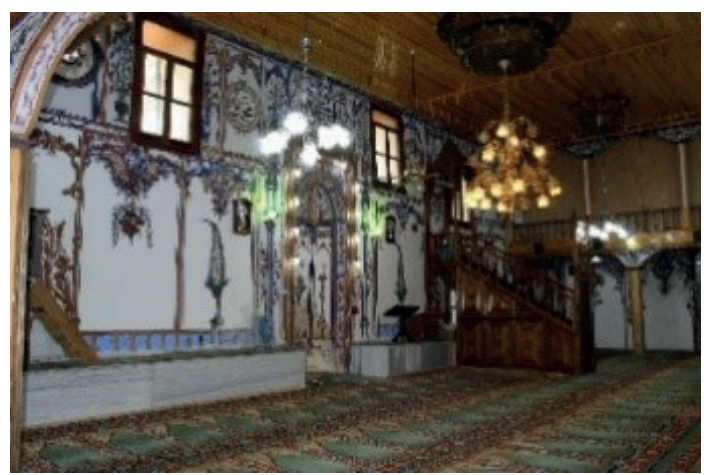

F. 19: Kırkoluk Cami, doğudan harime bakış 


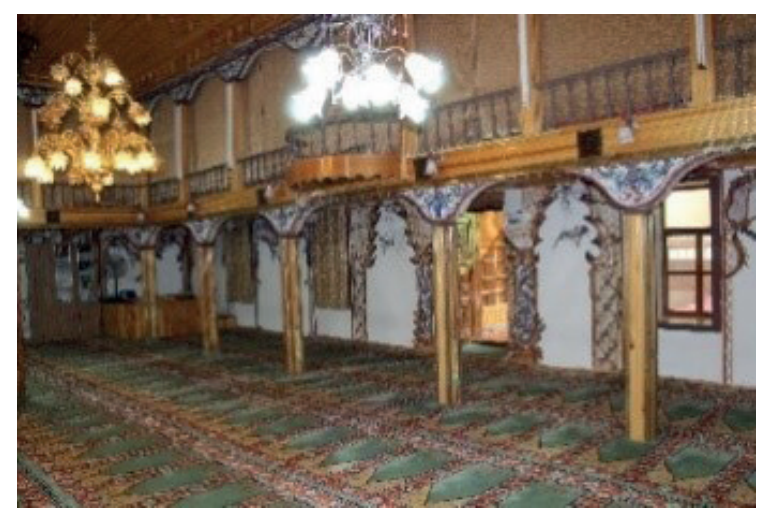

F. 20: Kırkoluk Cami, doğudan kadınlar mahfiline bakış

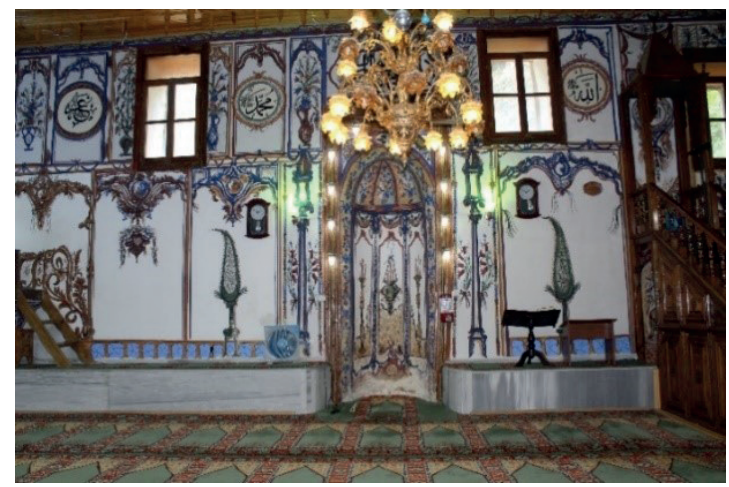

F. 21: Kırkoluk Cami, harim mihrap duvarına bakış

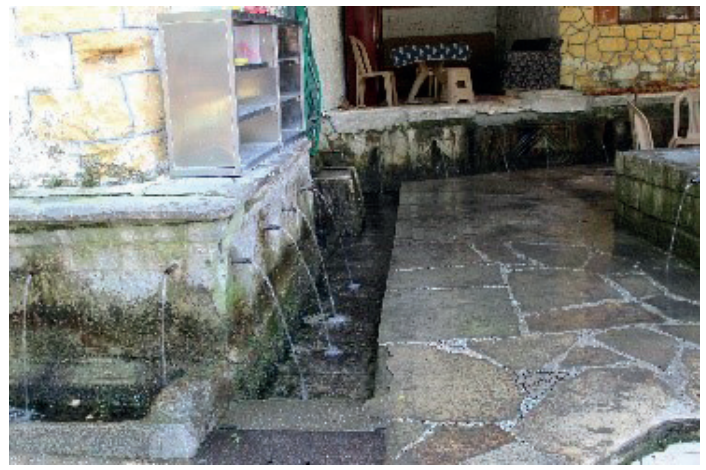

F. 22: Kırkoluk Cami, camiye adını veren ayna taşlı abdest muslukları 

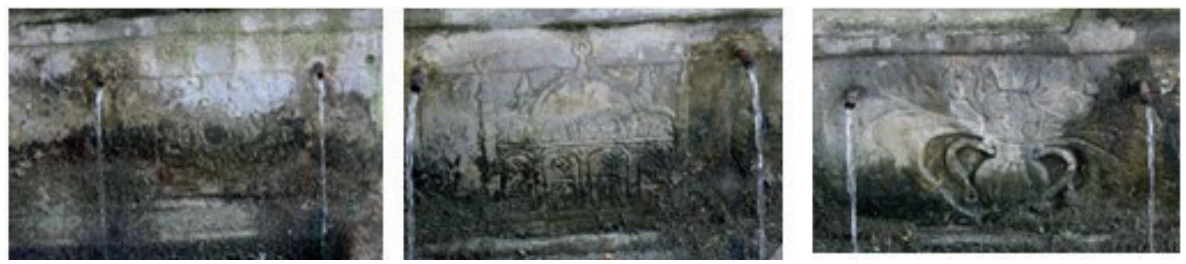

F. 23: Kırkoluk Cami, abdest musluklarının ayna taşlarından örnekler

\section{Minareli Cami}

Minareli Cami adıyla anılan eser, Tarhala'nın en tepe noktasında harim, mahfil, son cemaat mahalli ve yapıdan uzakta avlunun kuzeybatısında yer alan minareden meydana gelmiştir. ${ }^{34}$ Yapı, Kültür Bakanlığı Gayrimenkul Eski Eserler ve Anıtlar Yükssek Kurulu Başkanlığı'nın 8.7.1977 tarih ve A.633 sayılı kararıyla eski eser olarak tescillenmiştir. ${ }^{35}$

\section{Yapının Tarihi}

Yapının kitabesi bulunmadığı için kesin olarak ne zaman inşâ edildiği bilinmemektedir. İnşa tarihi konusunda; A. Etlacakuş, 16. yüzyıldan kalma tarihi bir belgede Tarhala' da bir caminin varlığından söz edildiğini belirtmiştir. Bu belge ve eserin minaresinin mimari özelliklerinin İzmir, Birgi, Ödemiş ve Güdük Minare Mescidi minarelerine benzerliğinden dolayı, camiyi 14. yüzyılın ikinci yarısına tarihlendirmiştir. ${ }^{36}$

M. Çerkez, minarenin güney yönündeki kapısı üzerinde 15. yüzyıla denk gelen tarih bulunduğunu ve minare üzerine konmuş Bizans dönemine ait devşirme parçalardan dolayı minarenin inşâ tarihinin 15. yüzyıl olma ihtimalini kuvvetlendirdiğini belirtmiştir. ${ }^{37}$

Caminin mimari karakter ve malzeme özelliklerinden 19. yüzyılda inşâ edildiği anlaşılmaktadır. Minarede kullanılan tuğla malzemenin form ve niteliği ise 14-15. yüzyıl gibi daha erken bir dönemi işaret etmektedir.

Kesme taş, moloz taş ve tuğla malzemeden inşâ edilen minarenin taş ve tuğla aralarında çimento harç kullanılmıştır. Minare beden duvarı üzerinden ongen kürsü ve pabuç üzerinde, silindir gövdeli olarak yükselmektedir. Kürsü üzerine yerleştirilmiş Erken ve Orta Bizans dönemine ait devşirme parçalar dikkat çekmektedir. ${ }^{38}$ Pabuçtan gövdeye geçmeden önce yaklaşık $1 \mathrm{~m}$. yüksekliğinde betondan yapılmış ve üzeri çimentoyla sıvanmış küp bölümü

34 Minareli Cami fotolarını ve rölövelerini çalışmada kullanmama izin vererek çalışmama destek olan KÖK Mimarlık Ltd. Ști.'ne teșekkür ederim.

35 İzmir II Numaralı Kültür Varlıklarını Koruma Bölge Kurulu Arşivi.

36 Ayşen Etlacakuş, Conservation Aimed Evaluation of Darkale Rural Settlement in Soma, Manisa, Volume I, Master of Sciences, İzmir, 2015, s. 56.

37 Çerkez, a.g.e., s. 448.

38 Ermiş, a.g.e., s. 63; Zeren, a.g.e., s. 8; Ü. Melda Ermiş, "Darkale'deki Bizans Dönemine Ait Mimari Plastik Eserler”, Uluslararası XIX. Ortaçağ ve Türk Dönemi Kazları ve Sanat Tarihi Araştırmaları Sempozyumu, 21-24 Ekim 2015, Bildiriler, C.1, Ankara 2019, s. 575, 579. 
bulunmaktadır. Minarenin şerefesi demir korkulukludur ve şerefe altı testere dişlidir. Minarenin İçinden şerefeye çıkılan basamaklar betondur. Bu haliyle minarenin kürsü ve pabuç kısmının özgün olduğu, buradan itibaren beton, taş ve tuğla aralarında çimento harç kullanılarak yapılmış silindir gövde bölümünün sonradan yapıldığı anlaşılmaktadır. Fakat gövdede kullanılan tuğla malzemenin, kürsü ve pabuçta kullanılanlarla aynı form ve dönem olması, gövdenin yıkıldığını ve kendi malzemesiyle yakın zamanda yeniden inşâ edildiğine işaret etmektedir. Caminin minareden çok daha geç bir döneme ait olması ise şöyle izah edilebilir: Minareyle aynı tarihte yapılmış eski cami yıkılmış ve yerine 19. yüzyılda yenisi yapılmıştır (F29).

Eser sade, mütevazi boyutlarda bir yapıdır ve günümüzde ibadethane işleviyle restorasyon aşamasındadır.

\section{Yapının Mimari Özellikleri}

Eser, moloz taş malzemeyle inşâ edilmiş, duvar aralarında ahşap hatıllarla desteklenmiş ve kırma çatı ile örtülmüştür. Harim doğu batı yönünde dikdörtgen planlıdır ve harimin kuzeyinde kadınlar mahfili ve son cemaat mahallinden meydana gelmiştir. Caminin avlusunda kuzeybatıda yapıdan bağımsız minaresi bulunmaktadır (F24).

Caminin avlusuna batı cephe üzerinde bulunan devşirme ayaklara sahip kapıdan girilmektedir. Yapının kuzey cephesi doğu-batı yönünde uzanan son cemaat mahallidir. Son cemaat mahallini arazi şartlarına uydurmak için batı yönü içeri doğru eğimli yapılmıştır. Son cemaat mahalli kemer yüzeyleri bağdadi sıvalı, ahşap sütunlara oturmuş, altı yuvarlak kemerle avluya açılmıştır. Son cemaat mahallinin güney duvarı alt sırada iki, üst sırada üç pencerelidir. Alt sıradaki pencerelerin ortasında harime giriş kapısı açılmış ve bu kapının sağında yuvarlak kemerli mihrap nişi yer almıştır (F24-F25).

Caminin diğer cephelerinin düzeni şöyledir: Doğu ve batı cephelerinde iki pencere görülürken, yol kotundan aşağıda kalmış güney cephesinde ise hiç pencere bulunmaz (F26-F28).

Son cemaat mahallinden harime ahşap kanatlı ve pervazlı özgün kapıdan girilmektedir. Doğu-batı yönünde konumlanan harimin kuzeyi duvara bitişik halde dört ahşap sütun dizisiyle beş kemer gözlü olarak tasarlanmıştır. Kemer şekilleri en dıştakiler yarım daire, kuzeybatıdaki ikinci göz yuvarlak kemerli ve ortadakiler Bursa kemerlidir. Ortadaki kemer gözünde ahşap merdivenle çıkılan, mahfil yer almıştır. Merdiven ve mahfil ahşap korkulukludur ve mahfilden harime doğru yarım daire balkon uzanmıştır (F30). Harimin zemini taş ve ahşap, çatı ise ahşap çıtalar arasında yer yer kontrplak kaplamalıdır. Tavanda ahşap kaplamalar arasında üçü aynı hizada, biri mihraba yakın dört adet kare tavan göbeği bulunur. Mihraba yakın göbekte dört yöne bakan stilize palmet formu yerleştirilmiştir. Üçü aynı hizada olan göbeklerden ortadaki daire formlu güneş kursundan, iki yanındakiler ise kafes tekniğinde çıtalardan oluşmuştur (F30-F33).

Harimin doğu ve batı duvarları dikdörtgen biçimli, ikişer pencerelidir (F31, F33). 
Harimin güney duvarı düz devam ediyorken arazi şartlarından dolayı güneybatı bölümü içeri doğru kırılmaktadır. Mihrap yarım daire formlu niş ve tuğla örgülü yuvarlak kemerlidir. Güney duvarı boyunca yerden yaklaşık $1 \mathrm{~m}$. yüksekliğinde işlevi tam anlaşılamayan seki şeklinde bir duvar sırası uzanmaktadır. Mihrap nişinin sağında ahşap sade minber, solunda ise ahşap vaaz kürsüsü yer almıştır (F32).

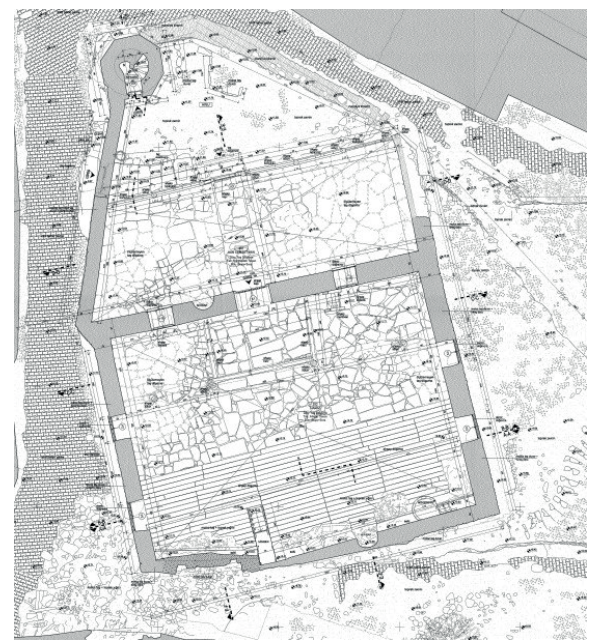

F. 24: Minareli Cami rölövesi (KÖK Mimarlık Ltd. Şti, Çizen Gürem F. Özbayar Sargın ve Zeynep Kutlu, 09.02.2018, İzmir II Numaralı Kültür Varlıklarını Koruma Bölge Kurulu Arşivi.)

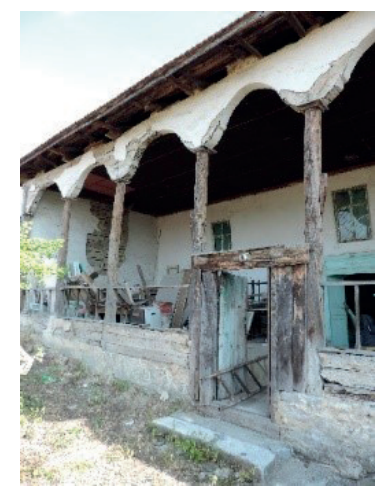

F. 25: Minareli Cami, kuzey cepheye bakış

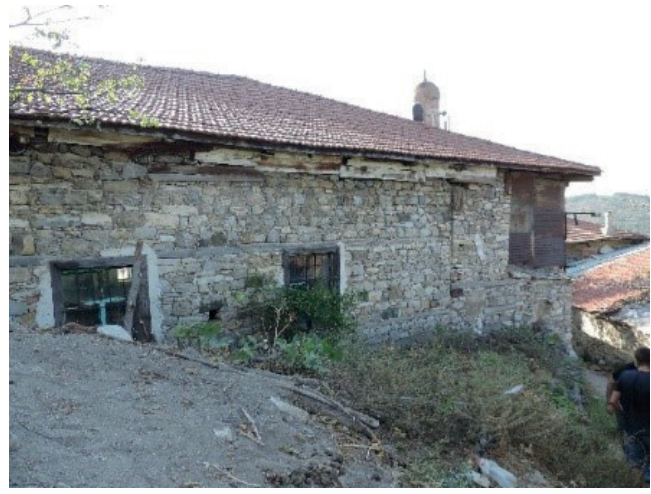

F. 26: Minareli Cami, doğu cepheye bakış 


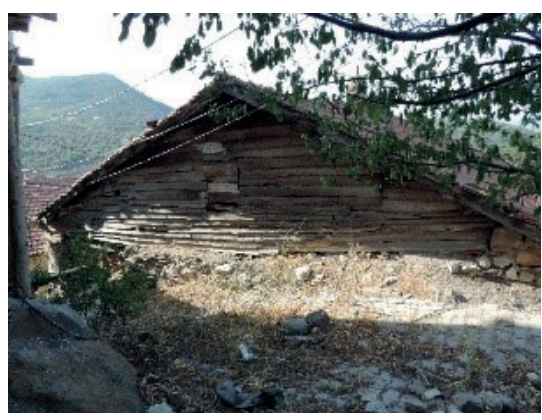

F. 27: Minareli Cami, güney cepheye bakış

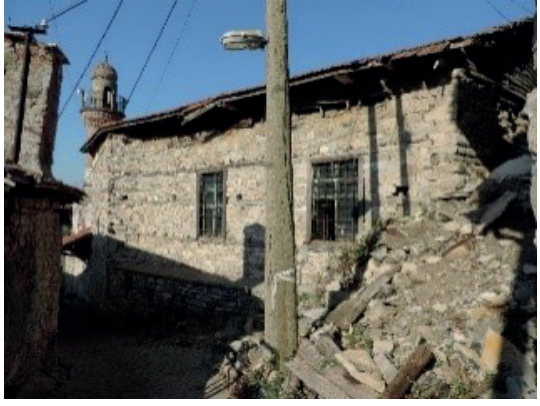

F. 28: Minareli Cami, bat1 cepheye bakış

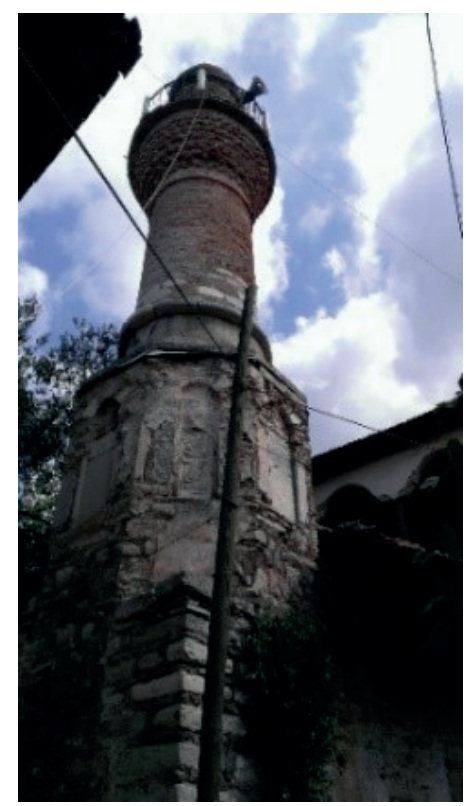

F. 29: Minareli Cami, minareye bakış 


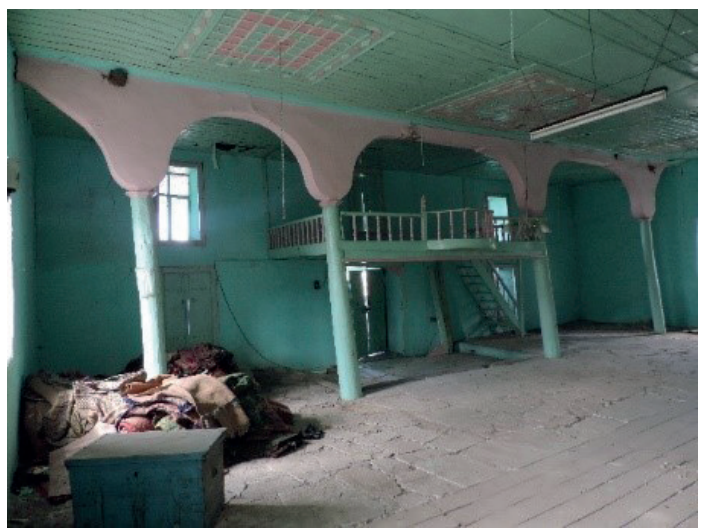

F. 30: Minareli Cami, kuzey duvarına bakış

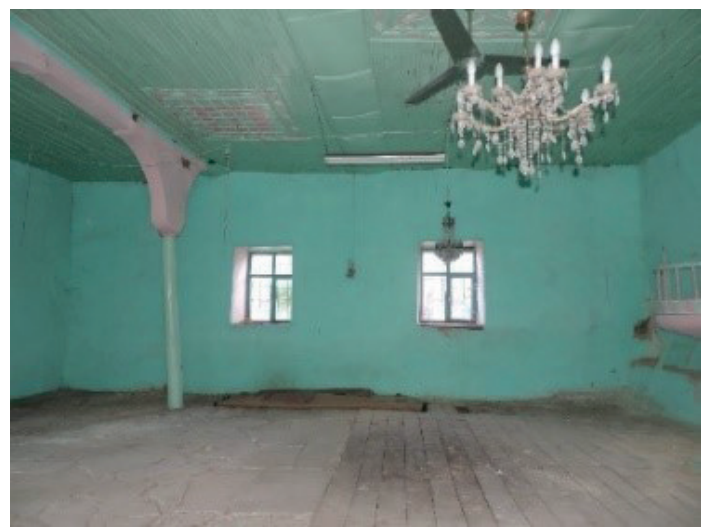

F. 31: Minareli Cami, doğu duvarına bakış

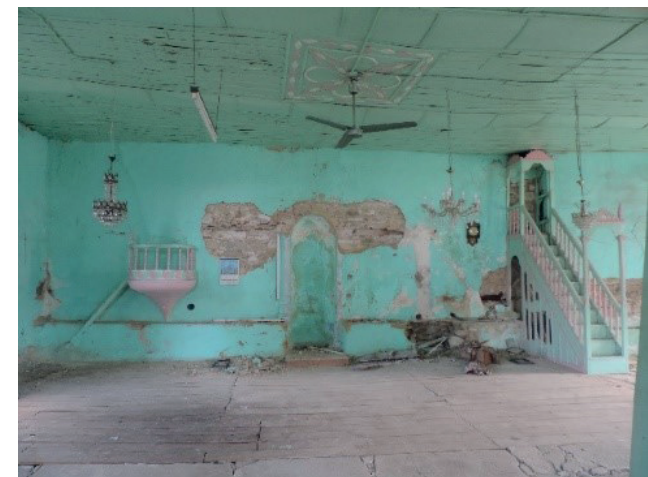

F. 32: Minareli Cami, güney duvarına bakış 


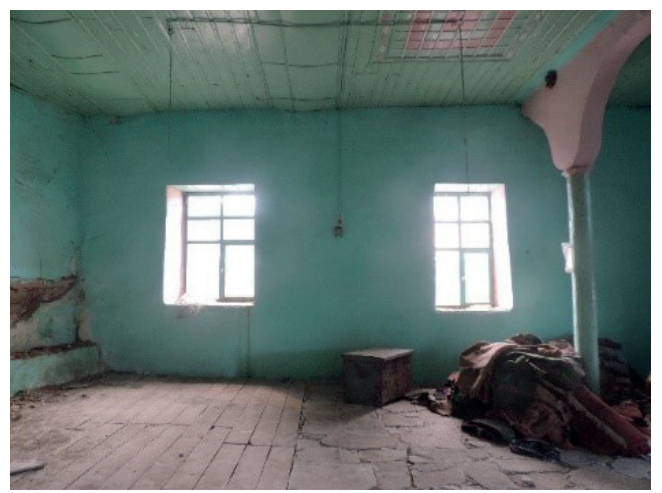

F. 33: Minareli Cami, batı duvarına bakış

\section{4. Çamaşırhane}

Köy meydanında, yolun kenarında, Kırkoluk Cami’nin güney duvarına bitişik vaziyette inşâ edilmiştir. Yapı, Kültür Bakanlığı Gayrimenkul Eski Eserler ve Anıtlar Yüksek Kurulu Başkanlığı'nın 8.7.1977 tarih ve A.633 sayılı kararıyla eski eser olarak tescillenmiştir. ${ }^{39}$

\section{Yapının Tarihi}

Yapıya ait inşâ kitabesi bulunmadığı için ne zaman yapıldığg kesin olarak bilinmemektedir. Yapının taş örgüsü, plan ve mimari formu erken bir döneme işaret etmektedir. Fakat daha önceden burada bir tabakhanenin bulunduğ $u^{40}$, çamaşırhanenin ise bitişiğinde bulunan Kırkoluk Cami’nin onarımları sırasında yani 19. yüzyılın sonu ile 20. yüzyılın başlarında sonradan inşâ edildiği ifade edilmektedir. ${ }^{41}$

Ancak, cami ile çamaşırhanenin mimari form ve özellikleri birbirinden oldukça farklıdır. Bize göre burası 14-15. yüzyıllarda tabakhane olarak inşâ edilmiş bir yapıyken, kuzey duvarına bitişik cami inşâ edilince, kokunun cami cemaatinin ibadetine engel olmaması için tabakhane işlevi terk edilerek çamaşırhane şeklinde kullanılmaya devam etmiştir. Çamaşırhanenin avlusunda güneyde yer alan su deposu/hazne ve çeşme yapıları ise, bu işlev değişikliğinde cami ile birlikte inşâ edilmiş olmalıdır.

\section{Yapının Mimari Özellikleri}

Yapının beden duvarları kaba yonu taş, tonoz kemerleri ise kesme taştır. Çamaşırhane, doğu-batı ekseninde eğimli bir arazinin içinde konumlanmış bir yapıdır. Yapı açık avlulu ve üç eyvanlı plan şemasındadır. Doğu cephede bulunan açıklıktan giriş mekânı olarak

39 İzmir II Numaralı Kültür Varlıklarını Koruma Bölge Kurulu Arşivi.

40 Arel, a.g.e., s. 122.

41 Çerkez, a.g.e., s. 459. 
tasarlanmış, yamuk planlı, üstü açık bölüme girilir. Buradan iki basamakla düşük kottaki avluya inilmektedir. Avlunun güneyinde su deposu, batı, kuzey ve doğusunda birer eyvan yer almaktadır. Batı eyvanı iki sivri kemerle avluya açılmış, sivri tonozla örtülmüş ve destek kemeriyle kuvvetlendirilmiştir. Eyvanın içinde yaklaşık $1 \mathrm{~m}$. yükseklikte çamaşır yıkama sekileri yapılmıştır. Moloz taş örgülü sekilerin üzerine atılmış kalın beton yakın zamana kadar yapının kullanıldığına işaret etmektedir (F34-F35).

Kuzey eyvanı caminin mihrap duvarına bitişik inşâ edilmiş, tek gözlü bir yuvarlak kemerle avluya açılmakta ve beşik tonozludur. Eyvanlar içinde en büyük olanı budur. Eyvanın batısında bulunan kapıdan hela olarak düzenlenmiş mekâna geçilmektedir (F34, F36).

Doğu eyvanı da tek gözlü yuvarlak kemerle avluya açılan, beşik tonoz örtülü bir mekândır. Eyvanın doğu duvarında sivri kemerli iki niş açılmış ve sekileri, batı eyvanında olduğu gibi sonradan betonla kaplanmıştır (F34, F37).

Eyvanların içlerinde yakılan ateşten dolayı taşlar isle kaplanmış, ocak yerleri de hâlâ yerindedir.

Yapının güneyinde kesme taştan inşâ edilmiş, yuvarlak kemerli ve nişi tahrip edilmiş çeşme bulunmaktadır. Çamaşırhanenin suyu bu çeşmenin altındaki bir borudan akmaktadır. Bugün yerinden sökülmüş olan boru, eski fotoğraflarda görülmektedir ${ }^{42}$ (F38). Çeşmenin nişinde kitabelik yerinde açılan delikten arkasında doğal suyla beslenen bir depo olduğu görülmektedir. Su deposu ortasından bir ayakla desteklenmiş, üzerleri sivri tonozla örtülü, üç gözlü bir yapıdır (F39).

Avlunun güneybatısından beş basamakla avlu kotundan yüksekte bulunan alana çıkılmaktadır. Bu alan muhtemelen yıkanan çamaşırların kurutulduğu bir bahçe olarak kullanılmıştır.

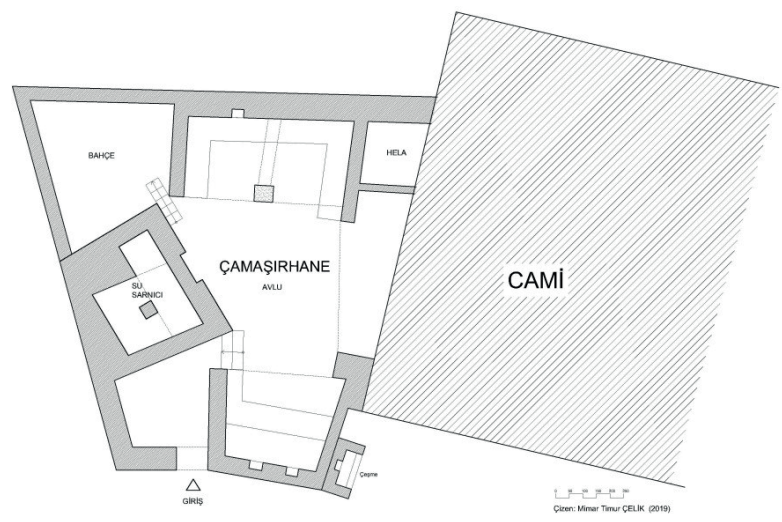

F. 34: Çamaşırhane planı (T. Çelik, 2019)

42 Çeşmenin ve avlu zemininde kanaldan akan suyun tahrip edilmeden önceki halini görmek için bk. Çerkez, a.g.e., s. 462 , F.4. 


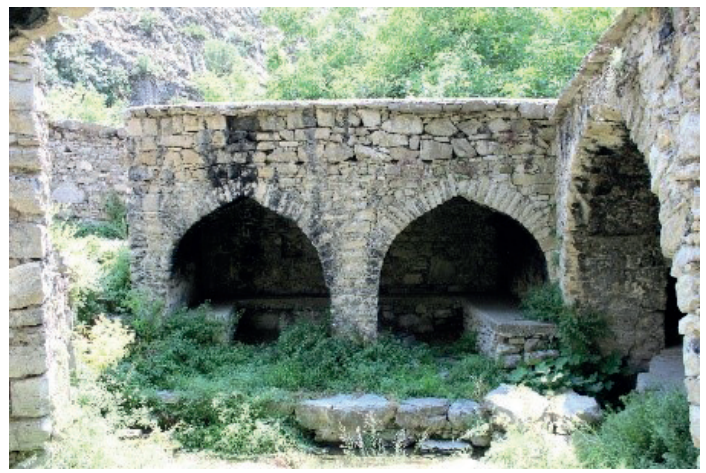

F. 35: Çamaşırhane, avludan batı eyvanına bakış

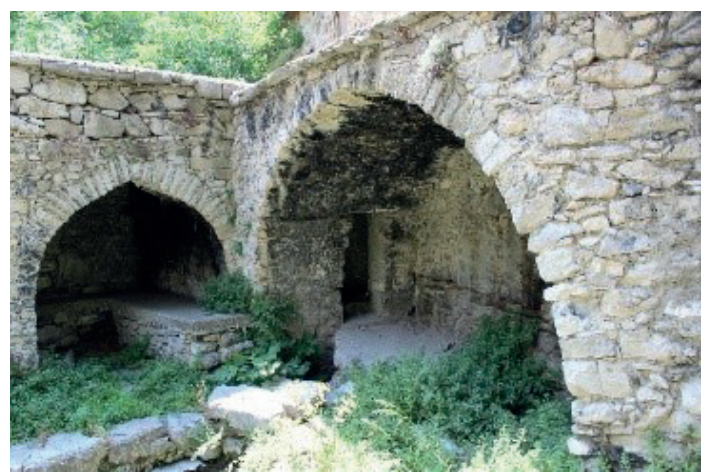

F. 36: Çamaşırhane, avludan kuzey eyvanı ve hela kapısının görünümü

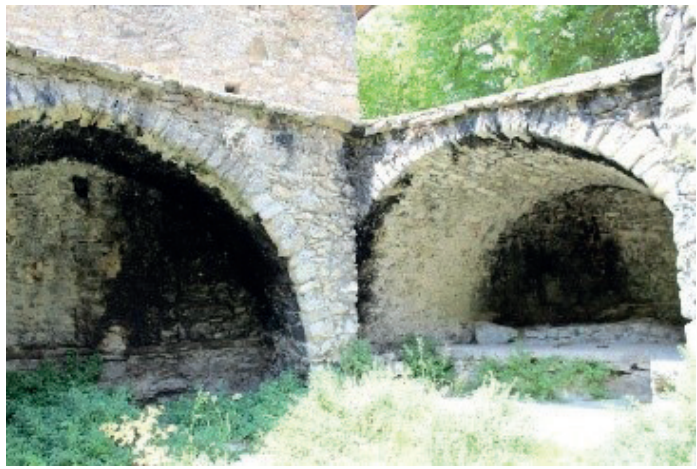

F. 37: Çamaşırhane, avludan doğu eyvanına bakış 


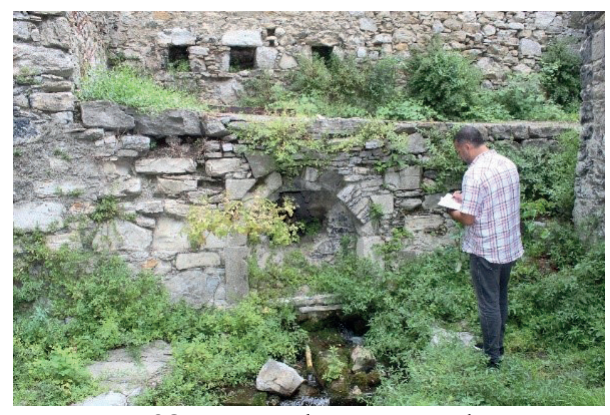

F. 38: Çamaşırhane, çeşmeden görünüm

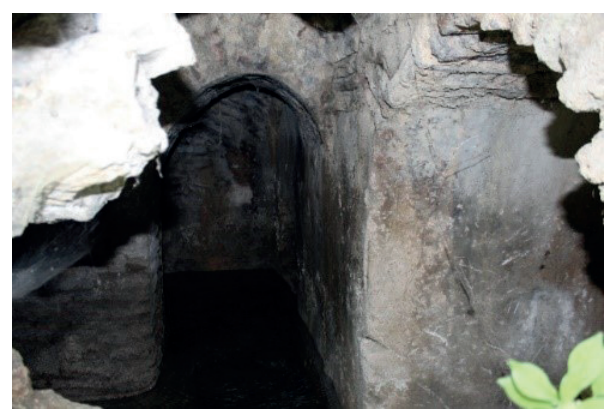

F. 39: Çamaşırhane, su deposunun içinden görünüm

\section{Kırkoluk Cami Çeşmesi}

Çeşme, Kırkoluk Cami'nin güneydoğusunda bir duvarla organik bağ içerisinde ve çamaşırhanenin duvarına bitişik vaziyettedir (F40). Kesme taş ve tuğla malzeme ile inşâ edilmiştir. Kitabesi yoktur, malzeme özellikleri ve kemer formu camiden daha önce yapıldığına işaret eder. Yaklaşık olarak 19. yüzyılda yapılmış olduğu söylenebilir. ${ }^{43}$ Yapı adeta eyvan gibi derin bir niş içerisinde ve sivri kemerli bir formda inşâ edilmiştir (F41). Sivri kemeri taşıyan ayaklardan sağdaki kuş figürlü süslemesi olan Bizans devşirme malzemedir ${ }^{44}(\mathbf{F 4 2})$. Çeşmenin üçgen biçimli tas nişi, su lülesi ve su teknesi/yalağı halen mevcuttur. Günümüzde de çeşme olarak kullanılmaktadır.

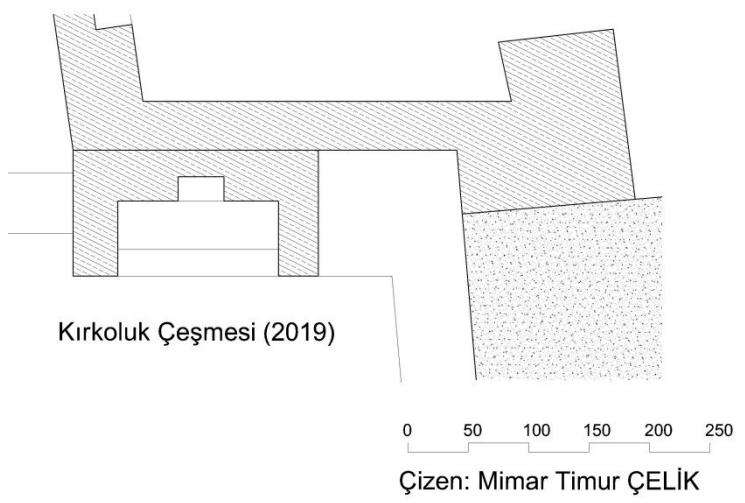

F. 40: Kırkoluk Cami çeşmesi planı (T. Çelik, 2019)

43 Çerkez, a.g.e., s. 465.

44 Ü. Melda Ermiş, "Darkale in The Byzantine Period: Settlement And Some Architectural Notes", Turkish Studies, Volume 11/1 Winter 2016, s. 68; Ü. Melda Ermiş, “Darkale'deki Bizans Dönemine Ait Mimari Plastik Eserler”, Uluslararası XIX. Ortaçağ ve Türk Dönemi Kazıları ve Sanat Tarihi Araştırmaları Sempozyumu, 21-24 Ekim 2015, Bildiriler, C.1, Ankara 2019, s. 586. 


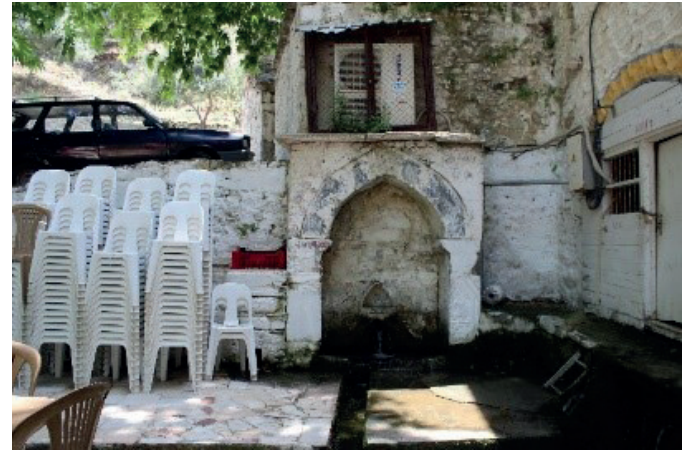

F. 41: Kırkoluk Cami çeşmesine bakış

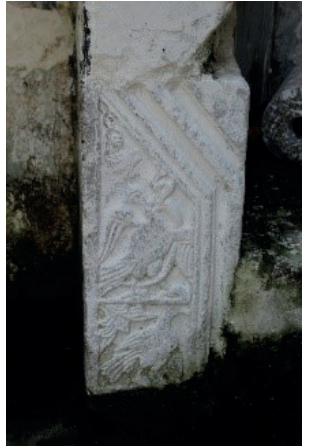

F. 42: Kirkoluk Cami çeşmesi devşirme malzeme

\section{Hacı Osman Hoca Zâde Çeşmesi}

Kırkoluk Meydanı'ndan, tepeye doğru çıkarken bir evin cephesine bitişik şekilde inşâ edilmiştir. Üzerindeki yazıta göre Hacı Osman Hoca Zâde'nin hayratı olarak 1228 (1813) yılında yaptırılmıştır.

Kitabe metni şöyledir:

1. Sahibü'l-hayrat ve'l-hasenat

2. Osman Hoca Zâde el-Ha-

3. c1 Muhammed Ğafurallahü lehüma ve setere

4. Afahima sene-i 1228

Çeşme nişi zeminden $78 \mathrm{~cm}$. yukarıdadır ve çift merkezli kaş kemer şeklinde tasarlanmıştır. Başlangıç noktasından itibaren kemer kilit taşına kadar $1.23 \mathrm{~m}$. yüksekliğinde, $78 \mathrm{~cm}$. genişliğinde ve $46 \mathrm{~cm}$ derinliğindedir. Kemer nişinin içinde $45 \times 33 \mathrm{~cm}$. ebatlarında dikdörtgen kitabe yer alır. Kitabe sülüs hatlı ve siyah boyayla yazılmıştır. Nişin içi çimento harç ile sıvanmış, su lülesi sökülmüş ve ayna taşı yoktur. Ayrıca tas yuvası ve su teknesi/ yalak gibi çeşmeye ait bölümler de bulunmamaktadır. Çimento harç sıvalı çeşmenin, niş derinliği ve kemer formu kesme taş olduğu düşündürmektedir. Günümüzde çeşme işlevini tamamen yitirmiştir (F43-F45).

A. Altıner, Tarhala Obası'nı anlattığı yazısında Tarhala'nın ilk kömür ocağını kuran Hacı Osman Ağa isimli bir şahsın başına gelen olaylar hakkında bilgiler vermektedir. ${ }^{45}$ Çeşme hayratını yaptıran Hacı Osman Ağa muhtemelen, Altıner’in sözünü ettiği şahıs olmalıdır.

45 Avni Altıner, “Tarhala Obasını Tanıyalım 4”, Gediz, Cilt Sayı 7, Manisa Halkevi Dergisi, 1937, s. 8. 


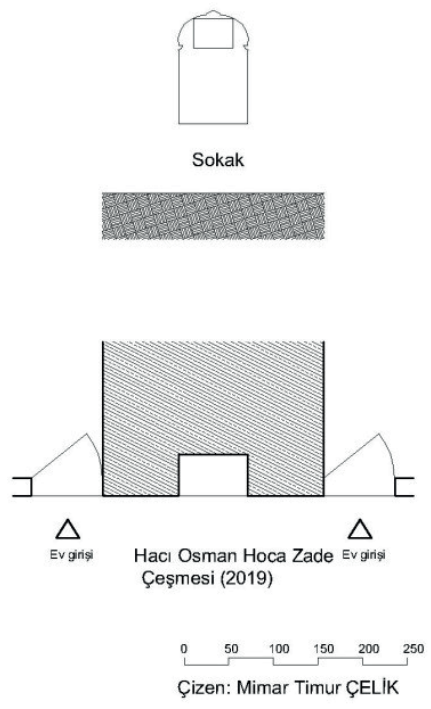

F. 43: Hac1 Osman Hoca Zâde Çeşmesi planı (T. Çelik, 2019)

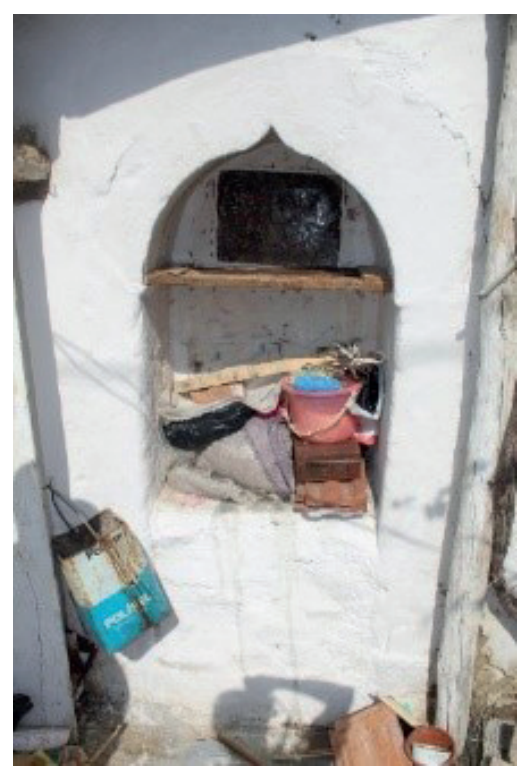

F. 44: Hacı Osman Hoca Zâde Çeşmesine bakış

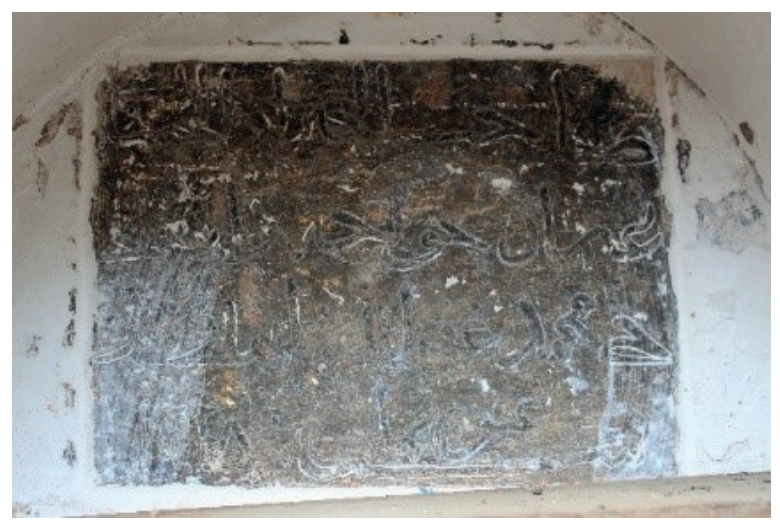

F. 45: Hacı Osman Hoca Zâde Çeşmesi kitabesi

\section{Kabak Pınarı Çeşmesi}

Kırkoluk Cami'nden, Minareli Cami’ye çıkan güzergâh üzerindedir (F46-F47). Kitabesi olmayan çeşme örgü tekniği ve malzemesine bakılarak 19. yüzyılın sonlarına tarihlendirilebilir. ${ }^{46}$ Çeşme, kaba yonu taş malzemeden örülmüş $2.25 \mathrm{~cm}$. açıklığında yuvarlak tonozlu bir eyvanın orta duvarındadır. Eyvanın sol yan duvarı $2.95 \mathrm{~cm}$. iken, bu derinlik sağ yan duvarda 2.53 
cm. oranında değişmektedir. Eyvan tonozunun yuvarlak kemeri, eyvanın iç yüzeyine doğru pahlanarak beden duvarının üzerine oturtulmuştur. Taş araları Horasan harcı dolguludur. Eyvanın ana duvarında bulunan çeşme nişi beden duvarından $25 \mathrm{~cm}$. içeride, bir sıra taş, bir sıra tuğla örgülü ve yuvarlak kemerlidir. Kemer girintili sütunçe başlıklarına oturtulmuştur. Çeşmenin önünde kaba yonu taş örgülü yalak/su teknesi, yalağın iki yanında ise birer seki yer almıştır. Günümüzde çeşmenin nişi çimento katkılı harç ile sıvalı olduğundan çeşmeye ait su tası ve tas yuvası gibi bölümler görülmemektedir. Nişin kemer başlangıcı ile kilit taşı arasındaki mesafe eskiden burada bir kitabe olabileceğini düşündürmektedir. Nişin sağ tarafında ise çeşmenin arkasındaki su haznesinin temizlenebilmesi için geniş bir açıklık mevcuttur. Hazne içi hidrolik sivalidir (F46-F48).

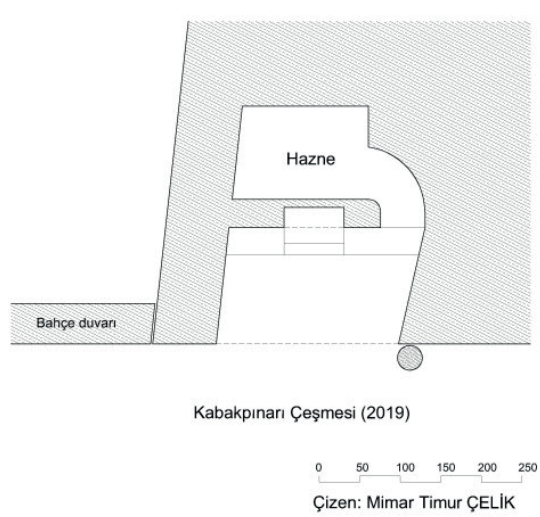

F. 46: Kabak Pınarı Çeşmesi planı (T. Çelik, 2019)

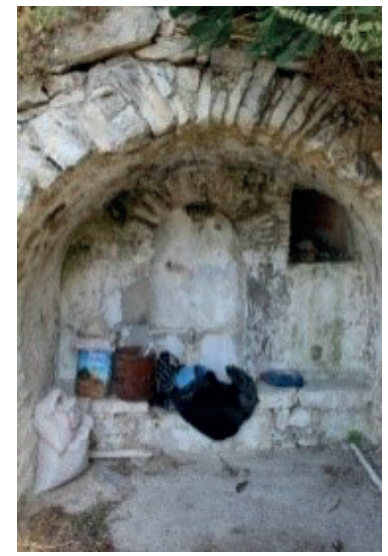

F. 47: Kabak Pınarı Çeşmesi eyvandan ayrint 1

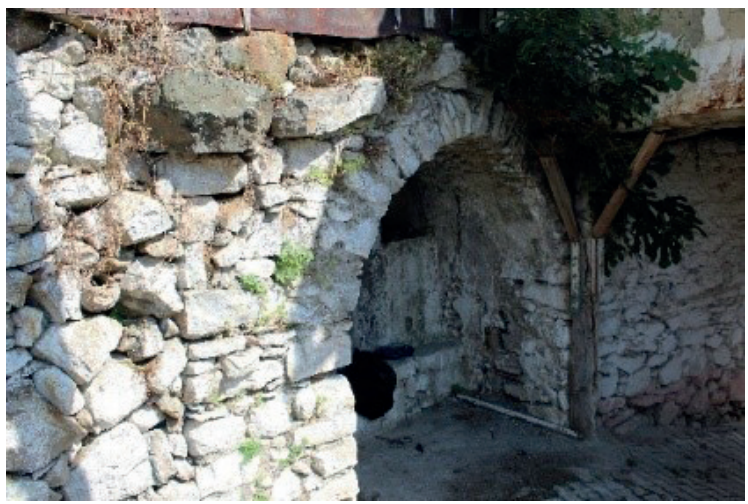

F. 48: Kabak Pınarı Çeşmesine bakış 


\section{Körpeler Çeşmesi}

Bir evin cephesi üzerinde kesme taş malzemeyle inşâ edilmiştir. Kitabesi olmadığ 1 için tarihi bilinmez, fakat malzeme ve form 19. yüzyıl olduğunu düşündürmektedir. Sivri kemerli niş $73 \mathrm{~cm}$ genişliğinde ve $55 \mathrm{~cm}$ derinliğindedir. Çeşmenin lülesi sökülmüş, tas için yuva da bulunmamaktadır. Tek parça taştan yapılmış su teknesi hâlâ yerinde durmaktadır. Nişin içi belli bir mesafeye kadar moloz taşla doldurulmuştur (F49-F50). Günümüzde çeşme işlevini yitirmiştir.

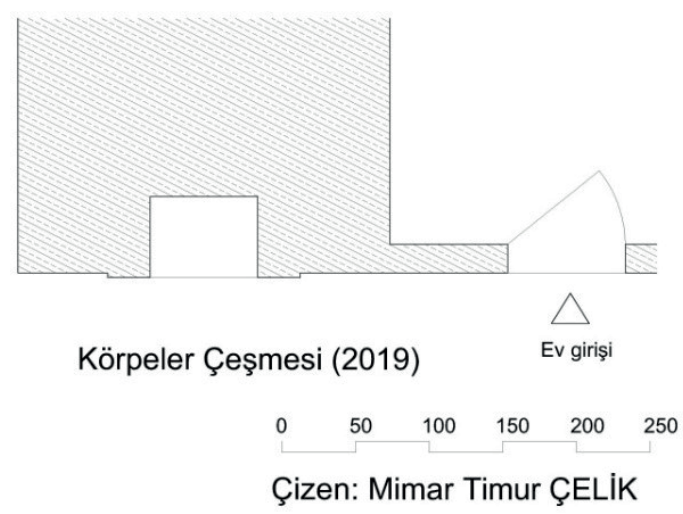

F. 49: Körpeler Çeşmesi planı

(T. Çelik, 2019)

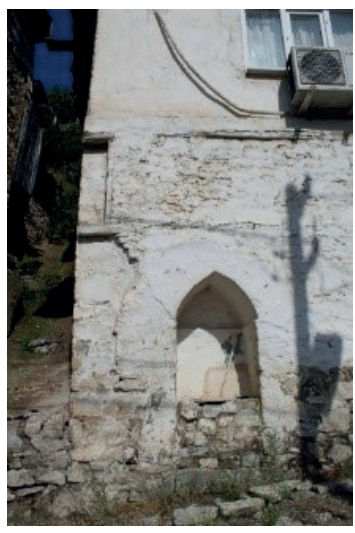

F. 50: Körpeler Çeşmesine bakış

\section{Minareli Cami Çeşmesi}

Minareli Cami'nin, avlu giriş kapısının solunda avlu duvarına bitişik şekilde inşa edilmiştir (F51-F52). Günümüzde kitabesi bulunmaz ancak niş içindeki izler eskiden burada bir kitabe olabileceğini düşündürür. Yapı tarihi bilinmemekle birlikte kesme taş malzeme ve form olarak 19. yüzyıla tarihlendirilebilir. ${ }^{47}$ Sivri kemerli bir nişe sahip çeşmenin tas yuvası yoktur. Zamanında iki lülesi varken bunlardan biri kapatılmış, diğeri hâlen kullanılmaya devam etmektedir. Ayrıca önünde düzgün kesme taştan su teknesi/yalak bulunmaktadır (F51-F52).

47 Çerkez, a.g.e., s. 467. 


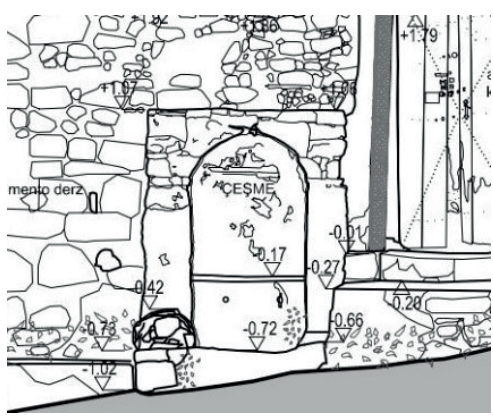

F. 51: Minareli Cami çeşme rölövesi. (Çizen Gürem F. Özbayar Sargın ve Zeynep Kutlu, Kök Mimarlık Restorasyon Ltd. Ști., KVMGM İzmir Rölöve ve Anıtlar Müdürlüğü, 2018)

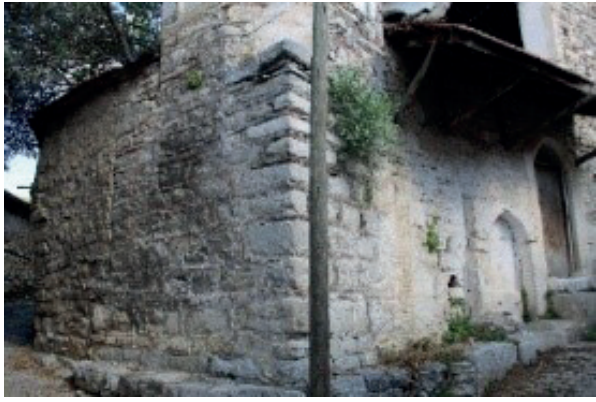

F. 52: Minareli Cami çeşmesine bakış

\section{0. ve 11. Delikanlı Odası Çeşmesi ve Koca Oda Çeşmesi}

Minareli Cami’ye doğru giderken günümüzde ancak yerleri kalmış metruk halde iki çeşme görülmektedir. Bunlar yöre halkının tabiriyle Delikanlı Odası Çeşmesi ve Koca Oda Çeşmesi'dir. Kalıntılardan anlaşıldığı kadarıyla her ikisi de kaba yonu taş örgülü ve Horasan harcı sıvalıdır. Tarihleri veya mimari karakterleri hakkında bilgi verebilme imkânı yoktur. Lüle yerleri hâlâ görülebilmektedir. (F53-F54).

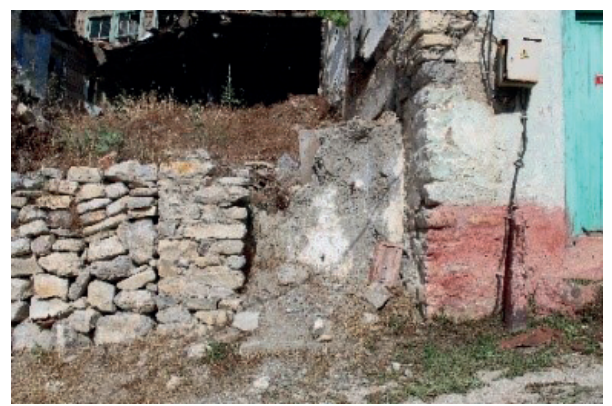

F. 53: Delikanlı Odası Çeşmesi

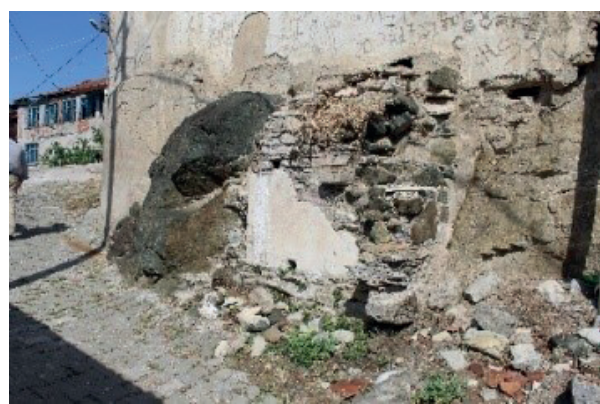

F. 54: Koca Oda Çeşmesi

\section{DEĞERLENDİRME ve KARŞILAŞTIRMA}

Kültür Bakanlığı Gayrimenkul Eski Eserler ve Anıtlar Yüksek Kurulu Başkanlığı'nın 8.7.1977 tarih ve A.633 sayılı kararıyla Darkale'de on dört yapı korunması gerekli eski eser olarak tescillenmiştir. Yerleşim daha sonra, Taşınmaz Kültür ve Tabiat Varlıklarını Koruma Yüksek 
Kurulu Başkanlığı'nın 24.02.1984 tarih ve 134 sayılı kararıyla sit alanı olarak tescillenmiştir. En son, İzmir II Numaralı Kültür Varlıklarını Koruma Bölge Kurulu'nun 24.01.2012 tarihli ve 448 sayılı kararı ile sit türü “Kentsel Sit” olarak belirlenmiştir. Ayrıca İzmir II Numaralı Kültür Varlıklarını Koruma Bölge Kurulu'nun 28.03.2013 tarih ve 2047 sayılı kararı ile Kentsel Sit, I. ve III. Derece Arkeloljik Sit Alanlarının sınırları belirlenmiştir. ${ }^{48}$

Tarhala' da Osmanlı döneminden günümüze iki özgün cami ulaşmıştır. Her iki caminin mimari form ve özellikleri 19. yüzyıl içinde, yakın zamanlarda imar edildiklerini göstermektedir. Bu camilerden Minareli Cami’nin, minaresi özelinde konu ele alınacak olursa, minarede kullanılan malzemenin biçim ve niteliği 14-15. yüzyılı işaret etmekte hatta Osmanlı öncesine bile gitme ihtimali bulunmaktadır.

Camilerin, mihrap duvarına göre enine uzanan harim ve harimin kuzeyinde son cemaat mahallinden meydana gelen planları yaklaşık olarak aynıdır. Son cemaat mahallinde görülen ahşap sütunlu kemer dizilerini birbirine bağlayan Bursa kemer formları da benzerdir. Tarhala' da bu kemer formuna konutların bahçeye bakan sofalarında kullanılmış örneklerine de rastlanmaktadır. Bölgede İslamiyet öncesi yaşamın tanığı olan devşirme malzemelerde bu iki camiye taşınmıştır. Minareli Cami’nin minare kürsüsü ve avluya giriş kapısının ayaklarında, Kırkoluk Cami'nin ise çeşme aynalarında Bizans döneminden kalma parçalar kullanılmıştır. Her iki caminin de suyla ilişkili yapılar şeklinde karşımıza çıkması önemli bir ayrıntıdır. Minareli Cami’nin avlu batı köşesinde duvara bitişik vaziyette; Kırkoluk Cami’nin güney doğusunda da camiyle bir duvarla bağ kuran çeşme yapıları bulunmaktadır.

Minareli Cami sade bir eser ve az miktarda ahşap tavan süslemesine sahipken, Kırkoluk Cami Batılılaşma üslubunda yapılmış kalem işi süslemeleriyle göz doldurmaktadır. Ne var ki özgün kalem işleri tahrip edilmiş ve üzerinden yağlı boyayla geçilmiştir. Her iki yapının statiğinde bozulmalar görülmekte ve ciddi onarımlar gerekmektedir. Minareli Cami restorasyon aşamasındadır. Kırkoluk Cami’nin son cemaat mahallinin batı duvarı ve harimin güney duvarı yoğun nem almaktadır. Bir an önce onarım yapılarak derzlerin patlaması ve sıvaların dökülmemesi için tedbirler alınmalıdır.

Tarhala'nın bağlı olduğu Soma ve köylerinde Kırkoluk ve Minareli Camilerin planlarına çok fazla yapıda rastlanmaz. Damgacı Cami (19. yüzyıl başı), Hamidiye Cami (1898) ve Bayat Köyü Orta Cami'nde ise (19. yüzyıl sonu) son cemaat mahalli ve harim planları benzerdir.

Damgacı Cami ve Hızır Bey Cami (1791-92) son cemaat mahalli kemer biçimleri ve duvar süslemelerinde görülen Barok karakterli çiçekler Kırkoluk Cami bezemeleriyle kıyaslanabilir. Ancak Hızır Bey ve Damgacı Cami'nde yoğun olarak karşımıza çıkan meyveler, gemi ve mimari tasvirler Kırkoluk Cami’nde görülmez. Soma Sevişler Köyü Cami (1802) tavan göbekleri ile Minareli Cami tavan göbekleri de oldukça benzemektedir. ${ }^{49}$

Yerleşim alanının mimari yapıları içinde belki de en ilginç olanı, açık avlulu ve üç eyvanlı

48 İzmir II Numaralı Kültür Varlıklarını Koruma Bölge Kurulu Arşivi.

49 Camilerin plan ve süslemeleri için bk. Çerkez, a.g.e., s. 377-387, 396-400, 479. 
düzende yapılmış çamaşırhanedir. Çamaşırhanenin inşâ tarihi hakkında kesin bilgilere sahip değiliz, fakat bu yapının bölgenin ilk Türk yerleşimine dair önemli bilgiler verebilecek bir mimari görünümde olması, üzerinde durulması gereken ciddi bir konudur. Çamaşırhanenin, Kırkoluk Cami'nin güney duvarına dayanmış olarak inşâ edilmiş olması, camide geçen 1264 (1847-1848)" ve “1321 (1903-1904)" tarihleriyle eş zamanlı olduğu ve adı geçen tarihlerde inşâ edilmiş olabileceği düşünülmüştür. ${ }^{50}$ Ancak yapının ne malzemesi, ne de mimari biçim ve karakteri camiyle hiçbir benzerlik/uyumluluk göstermez. Özellikle plan şeması ve kemer formları yapının adeta 14-15. yüzyıllarda inşâ edilmiş açık avlulu, eyvanlı bir mimari olduğu izlenimini vermektedir. Burada eskiden bir tabakhane varken, yerine çamaşırhane yapıldığı bilgisi, yeni bir yapı inşâ edilmek yerine mevcuttaki eski yapının çamaşırhaneye dönüştürüldüğüne işaret etmektedir.

Manisa'nın ilçelerinde ve köylerinde günümüze ulaşabilmiş başka bir çamaşırhane yapısı bilinmemektedir. Anadolu'da köy ve kasabalarda bu yapılardan zamanımıza ulaşabilen çok sayıda örnek mevcuttur. Bazılarını anacak olursak; Çankırı, Bolu Babahızır Köyü, Karabük Zopran Köyü, Safranbolu Yörük Köyü, Vezirköprü Adatepe Köyü, Gökçeada Çınarlı Köyü ve Bor Gökbez Köyü Çamaşırhanelerini sayabiliriz. ${ }^{51}$

Anadolu' da ki çamaşırhanelerin çoğu açık bir avlunun etrafında sıralanan yunak taşları ve ocak nişleri ile çevrili mekânlar şeklinde benzer özellikler sergilerler. ${ }^{52}$ Tarhala Çamaşırhanesi ise bu yapıların hiçbirine benzemez, açık avlulu, üç eyvanlı ve kapalı hacimleriyle ünik bir örnektir.

Yerleşimde suyun bol olması sebebiyle çok sayıda çeşme yapılmıştır. Çeşmelerin tamamı bir yapı ile organik bağ içerisindedir, bir konutun ve ya caminin parçası şeklinde sokakla uyumludur.

Çeşmelerin tamamında su teknesi/yalak haznesi bulunurken, su tası, tas yuvası gibi bölümler günümüze ulaşmamıştır. Bunlardan yalnızca Kırkoluk Cami çeşmesinde üçgen biçimli tas yuvası, su lülesi ve su teknesi/yalağı hâlen mevcuttur.

Eserlerden yalnızca bir tanesi kitabesini koruyabilmiştir. Eser kitabede adı geçen Hacı Osman Hoca Zâde tarafından 1228 (1813) yılında hayrat olarak yaptırılmıştır. Eser tarih vermesi bakımından önemlidir; zira yerleşimdeki diğer çeşmelerin tarihlendirmesinde yardımcı olmaktadır.

Çeşmelerin hepsinde malzeme ve kemer formları birbirlerine benzemektedir. Böylece 19. yüzyılda yapıldığını öğrendiğimiz Hoca Zâde çeşmesinden hareketle bütün çeşmelerin aynı yüzyılda yapıldığını söyleyebiliriz. Çeşmeler içinde Kabak Pınarı Çeşmesi bir eyvan içinde inşâ edilmesi bakımından diğerlerinden farklıdır. Ancak malzeme ve kemer formu diğerleriyle aynıdır.

Çalışmada müstakil başlıklar altında ele aldığımız eserler dışında nispeten daha yakın tarihli üç örnek göze çarpar. Cumhuriyet döneminde bölgede madenciliğin gelişmesiyle, köy yaşamında değişiklikler olmuş ve ortaya çıkan ihtiyaçlara göre yeni yapılar inşâ edilmiştir.

50 Çerkez, a.g.e., s. 459.

51 Betül Özcan Balkır, Çankırı (Merkez İlçe ve Köyleri) Türk Dönemi Mimari Eserleri, Gazi Üniversitesi, S.

B. E., Yayımlanmamış Doktora Tezi, Ankara 2018, s. 868-870.

52 Balkır, a.g.e., s. 867-872. 
Kamu binası olan bir ilkokul, ticaret yapısı olan bir zeytinyağı değirmeni ve ibadethane olan bir cami bu değişimin tanıkları olarak karşımıza çıkar. Köyün terkedilmesi sebebiyle kilitli olan bu yapılara giremediğimiz için içlerini inceleyemedik.

Tarhala'nın yamaçlarına doğru uzanan yerleşimin merkezinde Orta Cami yer almıştır. Cephe özelliklerinden konut olduğu anlaşılan yapının alt katı muhtarlık, üst katı ise mihrap, minber ve kadınlar mahfili eklemeleriyle camiye çevrilmiş bir örnektir. Cumhuriyet döneminde köydeki değişimle birlikte ortaya çıkan ihtiyaç nedeniyle konuttan camiye çevrildiği belirtilmiştir ${ }^{53}$ (F55-F56).

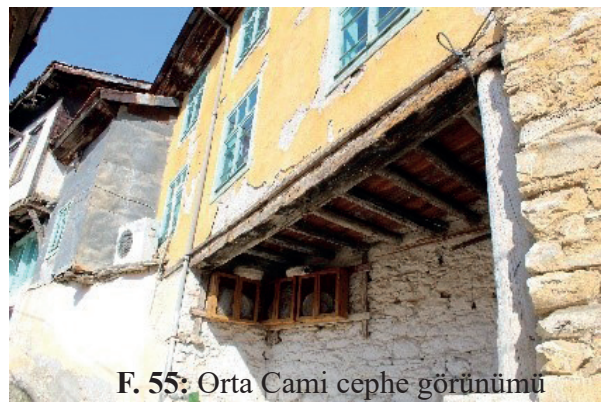

F. 55: Orta Cami cephe görünümüí

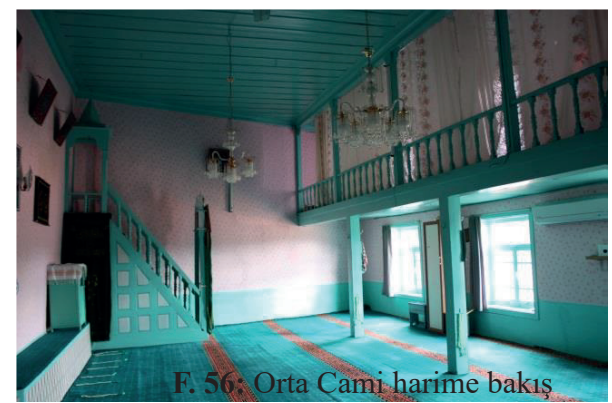

(Etlacakuş 2013, s. 60)

Köyün kuzey girişinde tabelasında, 1935 yılında İlçebay (Kaymakam) Hamdi Onat döneminde Tarhala Köyü tarafından yaptırıldığı belirtilen ilkokul bulunur. Okul bir avlu içinde, kaba yonu taş örgülü, tek katlı ve zemin seviyesinden yedi basamakla yükseltilmiş bir eserdir (F57).

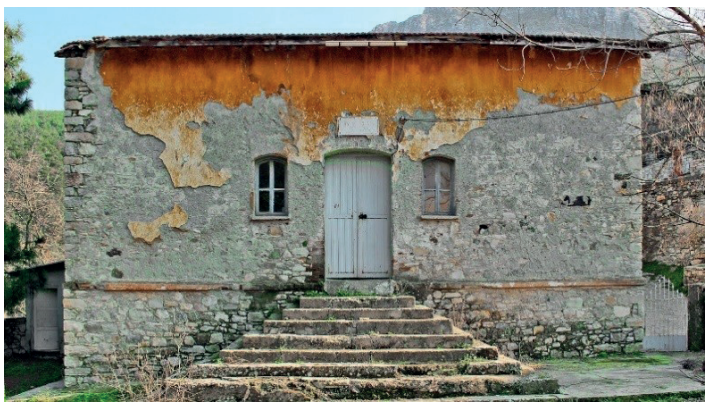

F. 57: Tarhala Köyü İlkokulu'na bakışş

53 Ayşen Etlacakuş ve Mine Hamamcıŏ̆lu Turan, "Historical Development of Darkale rural settlement in Soma, Manisa”, ITU A|Z, İstanbul, 2017, Vol 14 No 3, s. 20; Etlacakuş, a.g.e., s. 59-60, 163.

54 Çevrimiçi: https://sinirlarolmadan.blogspot.com/2019/05/orda-bir-koy-var-uzakta-tarihi-tarhala.html 13.05.2020 
Zeytinyağı değirmeni ise Darkale ve Soma arasındaki yolun batısındadır. Yapım tarihine dair bir kayda rastlanmaz, mimari karakteri ve benzerlerinden yola çıkılarak 19. yüzyılda yapıldığı düşünülmektedir. ${ }^{55}$ Taş örgü duvar tekniği ile inşa edilmiş ve tek katlıdır. Yapının işlevi ve bölgenin değişimi göz önüne alındığında Cumhuriyet döneminde yapılmış olabileceğine işaret etmektedir.

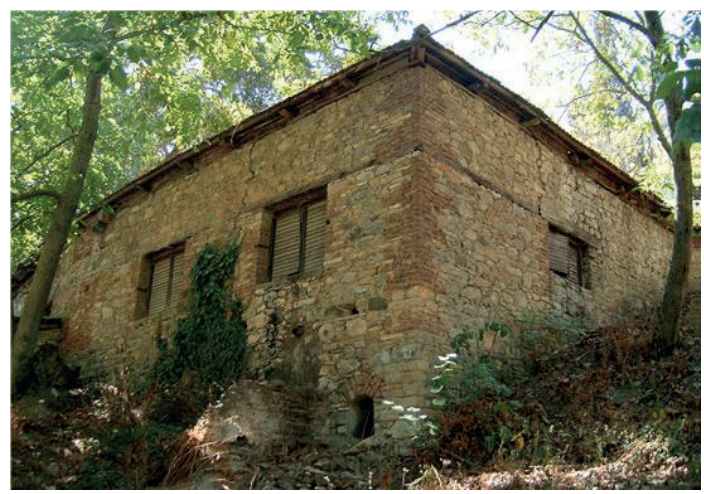

F. 58: Zeytinyağı değirmeni (Etlacakuş 2013, s. 65.)

\section{Sonuç}

Sonuç olarak; Tarhala köyü günümüzde neredeyse terk edilmiştir. Soma'da madencilik faaliyetlerinin sağladığı iş imkânları sebebiyle yaşam ilçeye taşınmıştır. Dolayısıyla kent yaşamının olmadığı bütün yerleşimler gibi burası da bütün tarihi eserlerini kaybetmek üzeredir. Camiler nispeten daha korunmuş olmakla birlikte, özellikle geleneksel konutlar büyük tahribata uğramıştır. Tarihi süreç içerisinde yapıların tescillenmesi ve bölgenin kentsel sit ilân edilmesi önemli adımlardır ama korumak için yeterli değildir. Bir an önce yaşayan bir kent olarak hayata geçirilebilecek çözümler üretilmeli, koruma amaçlı imar planı çıkartılmalı ve sokak sağlıklaştırma projeleri yapılarak uygulamaya konmalıdır.

Hakem Değerlendirmesi: Dış bağımsız.

Çıkar Çatışması: Yazar çıkar çatışması bildirmemiştir.

Finansal Destek: Yazar bu çalışma için finansal destek almadığını beyan etmiştir.

Peer-review: Externally peer-reviewed.

Conflict of Interest: The author has no conflict of interest to declare.

Grant Support: The author declared that this study has received no financial support.

55 Etlacakuş ve Turan a.g.e., s. 19; Etlacakuş, a.g.e., s. 65. 


\section{Kaynakça/References}

Akpınar Figen, "Bir Yerel Koruma Çabasının Öznesi Olarak Darkale Köyü”, Ege Mimarlık, Ocak 2016 s. 20-25.

Altıner Avni, "Tarhala Obasını Tanıyalım 4", Gediz, Cilt 1, Say1 7, Manisa Halkevi Dergisi, 1937, s. 8-9.

Altıner Avni, “Tarhala Obasını Tanıyalım”, Gediz, Cilt 3, Sayı 25, Manisa Halkevi Dergisi, 1939, s. 7.

Arel Ayda, "Soma Yakınlarında Eski Bir Dağ Yerleşmesi: Tırhala Köyü” IX. Araştırma Sonuçları Toplantısı, Çanakkale, 27-31 Mayıs 1991, A. Ü. Basımevi, Ankara 1992, s. 119-130.

Balkır Betül Özcan, Çankırı (Merkez İlçe ve Köyleri) Türk Dönemi Mimari Eserleri, Gazi Üniversitesi,

S. B. E., Sanat Tarihi A. D. (Yayımlanmamış Doktora Tezi), Ankara 2018.

Çerkez Murat, “Soma İlçesi”, Türk Kültür Varlıkları Envanteri 45, Manisa İlçeleri, Ed. Hakkı Acun, TTK Yayınları, Ankara, 2013.

Emecen Feridun, "Hudâvendigâr", DİA, Cilt 18, 1998, s.285-286.

Ermiş Ü. Melda, "Darkale in The Byzantine Period: Settlement And Some Architectural Notes", Turkish Studies, Volume 11/1 Winter 2016, s. 59-76.

Ermiş Ü. Melda, "Darkale'deki Bizans Dönemine Ait Mimari Plastik Eserler”, Uluslararası XIX. Ortaçağ ve Türk Dönemi Kazıları ve Sanat Tarihi Araştırmaları Sempozyumu, 21-24 Ekim 2015, Bildiriler, C.1, Ankara 2019, s. 573-599

Etlacakuş Ayşen, Conservation Aimed Evaluation of Darkale Rural Settlement in Soma, Manisa, Volume I,

Degree of Masters of Sciences in Architectural Restoration, Graduate School of Engineering and Sciences of İzmir Institute of Technology, İzmir, 2015.

Etlacakuş Ayşen ve Hamamcioğlu Mine Turan, "Historical Development of Darkale rural settlement in Soma, Manisa", ITU A|Z, İstanbul, 2017, Vol 14 No 3, s. 13-23.

Gökçen İbrahim, Saruhan'da Yörük ve Türkmenler, Marifet Basımevi, İstanbul, 1946.

Gökçen İbrahim, Manisa Tarihinde Vakıflar ve Hayırlar I, Marifet Basımevi, İstanbul, 1946.

Günay Vehbi, “XVI. Yüzyılda Tarhala Örneğinde Batı Anadolu'da İskân Değişimi”, Tarih İncelemeleri Dergisi, Cilt XXI, Say1 1, 2006, s. 107-122.

İlhan Gamze, Manisa Soma'da Bulunan Türk Devri Yapıları, Çanakkale Onsekiz Mart Üniversitesi, S. B. E., (Yayımlanmamış Yüksek Lisans Tezi), Çanakkale, 2019.

Kutlusoy İhsan, Soma, Tan Matbaası, İstanbul 1971.

Ramsay W. M., The Historical Geography of Asia Minor, Volume IV, Royal Geographical Society, Supplementary Papers, London 1890.

Uçarkuş Gülşah, Manisa Soma Darkale Mahallesi Geleneksel Konutları, Trakya Üniversitesi S. B. E., Sanat Tarihi A. D. (Yayımlanmamış Yüksek Lisans Tezi), Edirne 2019.

Uluçay Çağatay ve Gökçen İbrahim, Manisa Tarihi, Resimli Ay Matbaası, İstanbul, 1939, s. 22-23.

Uzunçarşı1ıoğlu İsmail Hakkı, Kitabeler II, Devlet Matbaası, İstanbul, 1347/1929.

Zeren Mine Tanaç, "Soma-Darkale Kültür Mirasının Korunması Ve Yerel Kalkınmanın Sağlanması İle İlgili Bilimsel Görüş (Rapor) Taslak”, Dokuz Eylül Üniversitesi Mimarlık Fakültesi Mimarlık Bölümü, Mart 2011, s. 1-20. 